\title{
ESTIMATION AND PREDICTION OF THE SOIL EROSION RISK INFLUENCED BY THE URBANIZATION PROCESS WITHIN A COUNTY IN HILLY AREA OF SOUTHEAST CHINA, USING RUSLE AND CLUES MODEL
}

\author{
FAN, J. ${ }^{1}-$ YAN, L. $^{1 *}-$ WU, L. ${ }^{1}-$ ZHANG, P. ${ }^{1}-$ ZHANG, G. ${ }^{2}$ \\ ${ }^{1}$ College of Life Sciences, Zhejiang University, Zhejiang, Hangzhou 310058, PR China \\ (e-mail:fanji_990@hotmail.com-J.Fan) \\ ${ }^{2}$ Center for Geographic Information Systems, Georgia Institute of Technology \\ Atlanta, GA 30308, USA \\ *Corresponding author \\ e-mail: yanlj@zju.edu.cn; phone: +86-186-5811-1761,+86-571-8820-6605 \\ (Received $28^{\text {th }}$ Sep 2018; accepted $27^{\text {th }}$ Nov 2018)
}

\begin{abstract}
Soil erosion by water is a well-known environmental problem. Urbanization is a worldwide trend, leading to a drastic change of land use forms in local areas, and change in soil erosion risks. This research analyzed the soil erosion risks in the past two decades of Zhuji County, which is located in hilly area of Southeast China and is experiencing fast urbanization process, to evaluate the influence of the urbanization on soil erosion using Revised Universal Soil Loss Equation (RUSLE). Land use maps were developed by using CLUEs (the Conversion and Land Use and its Effect at Small regional extent) model to estimate the soil erosion risk in 3 different urbanization scenarios of 2020. The results showed that, during 1984 to 2009 , as the percentage of the urban and built-up area increased from $0.43 \%$ to $10.95 \%$, though the extreme erosion value did not have a clear trend, from 1984 to 2004, the percentage of area with soil erosion risk higher than medium level kept increasing from $3.23 \%$ to $6.34 \%$, the percentage of area with tolerable soil erosion risk was decreasing from $71.57 \%$ to $67.58 \%$. The scenario analysis showed that the change of the urban and built-up area would change the soil erosion risk significantly, especially the high and severe level erosion risk. Higher than medium level soil erosion risk is $7.49 \%$ in Scenario 1 with $15.33 \%$ urban and built-up area, $8.63 \%$ in Scenario 2 with $18.86 \%$ urban and built-up area, and $13.07 \%$ in Scenario 3 with $25 \%$ urban and built- up area. And the buffer zone analysis of a highway in the county also showed that the soil erosion risk correlated with the size of urban and built-up area. These results indicated that Zhuji County needs to pay more attention when urbanize in hilly area since it leads to more severe erosion risk without prevention measurements. And policies should balance the preservation of the agriculture land and the potential soil erosion risk during urbanization process.
\end{abstract}

Keywords: land use, scenario, urbanization

\section{Introduction}

Urbanization is a major trend all over the world. According to the world urbanization prospects, the population in the urban area was growing in a high speed. Until 2017, approximately $55 \%$ of the world population were urban residents. And United Nations estimated the urban percentage will reach 68\% till 2050 (United Nations, 2018). Compared to developed regions, the rate of urbanization is even higher in developing regions. As one of the developing countries with big population and rapid growth, China has experienced drastic urbanization in recent two decades driven by the economic revolution. According to China statistic yearbook, $57.35 \%$ of the population was urban until 2016 and in the next 30 years, the urbanization speed will remain at a high level.

As is well recognized, rapid urbanization brings huge pressure on the natural resources and environment (Chen, 2007; Barbera et al., 2010; Akhalkatsi et al., 2017; Op de Hipt et 
al., 2018), including soil. Soil is an important resource to human beings, which is not only the foundation of the terrestrial ecosystems, but also an indispensable part of biogeochemical cycles. Soil is considered as a non-renewable resource in hundred-year horizon, which means when soil is eroded, it is hard to recovered. In this aspect, soil conservation is a critical issue during rapid urbanization.

According to the previous researches, urbanization would influence the soil erosion in several aspects as follows. (1) Construction sites would scattered in the city area during the process of urbanization, not only in the central city, but also in the extended areas near farmland or in the hilly area, such as the construction of the road and the places along the road (De Oña et al., 2009; Trenouth and Gharabaghi, 2015). (2) Urbanization always companies with increased proportion of impervious surface. Though after the impervious surface is built, the erosion risk in the area it covered will be lower, the peripheral area in the watershed, however, would be confronted with more serious erosion risk because of the larger amount of runoff than before (Arnold and Gibbons, 1996; White and Greer, 2006; Biggs et al., 2010). (3) Urbanization also dramatically changes the land use types in the area. The main process is the increase of building land, and the decrease of agriculture land and forest. Agriculture land is occupying forest while building land is invading agriculture land. Sometimes, agriculture reclamation will occur at slope land, which leads to higher risk of soil erosion than plain area (Podmanicky et al., 2011; García-Ruiz, 2010). The change of the land use pattern can also change the hydrology process in the area, which is an important factor to soil erosion (White and Greer, 2006; Zhang et al., 2018; Boongaling et al., 2018).

Zhejiang province is a southeast coastal province of China, belonging to the Yangtze River Delta. This area has experienced the most rapid development in China during recent years. In the next three decades, the speed of urbanization will remain at a high rate. To reduce soil erosion, studying the impact pattern and estimating the erosion risk in different developing scenarios would be necessary.

RUSLE (Revised Universal Soil Loss Equation) is a widely applied model in estimating the average soil erosion amount per year (Ouyang et al., 2010; Thomas et al., 2018; Napoli et al., 2016). RUSLE was originally developed to estimate soil erosion amount at field scale (Renard et al., 1991). As the development of the GIS (Geographic Information System), RUSLE is gradually applied on soil erosion prediction and assessing the soil erosion risk at large scale, such as catchment or watershed (Park et al., 2011; Ostovari et al., 2017). Since RUSLE was a field scale model, lots of previous research devoted to adapt it to a large scale, especially in adjusting the algorithm of $\mathrm{L}$ and S factors (Van Remortel et al., 2001; Lewis et al., 2005; Qin et al., 2018). In this research, soil erosion risk was assessed by RUSLE. And the algorithm of LS factor was adjusted based on the research area's condition.

Some efforts have been done in soil erosion within regional and large watershed scales (Basile et al., 2010; Beskow et al., 2009; Boix-Fayos et al., 2009; Chen et al., 2017), but there is still few study done in county scale, especially in the coastal area of Southeast China. Soil erosion is usually studied in natural catchment or watershed. However, studying on an administrative area basis would be more meaningful in China for local policy makers to understand the impact of erosion in the whole region and take effective prevention measurements. In this research, a whole county was chosen as the study area.

The main objectives of this research have two folds. (1) Analyze the impact of urbanization in past 2 decades on the soil erosion risk in Zhuji County; (2) By scenario analysis, estimate the soil erosion risk with different urbanization intensities in the next 10 
years, and analyze the government policies' influence. This research will be useful to understand the impact of further development in the urbanizing areas and how to take effective prevention measurements, and can also provide guidance on erosion control for other less urbanized area in China.

\section{Methodology}

\section{Study area}

Zhuji County is located in the middle of Zhejiang province in the coastal area of Southeast China (Fig. 1). The center of the county is located at $29.72 \mathrm{~N}$ and $120.23 \mathrm{E}$, covering $2311 \mathrm{~km}^{2}$ area. The county belongs to Puyang River watershed, and has a typical subtropical monsoon climate characterized as hot and dry summer due to the subtropical anticyclone and generally cold and humid winter. The average precipitation and annual temperature are $1373.6 \mathrm{~mm} /$ year and $16.3^{\circ} \mathrm{C}$, respectively. There are 27 administrative districts (villages and towns) in the county. In the past three decades since Chinese economic reform, Zhuji County has undergone a fast society and economic development. The population (and GDP (Gross Domestic Product)) increased from 0.94 million (248.35 million RMB (Renminbi)) in 1978 to 1.18 million (109906 million RMB) by 2016 (Stastical Bureau of Zhuji City, 2017). And the built-up area in the county expanded rapidly.

\section{Soil characteristic}

According to the general survey of soil (GSCC (General Soil Classification of China) system), there are 66 soil species in total in the study area. Red soil and paddy soil are dominant in this area (which in ST system belongs to Ultisols and Inceptisols. (OSD OSSD, 1998; Deckers et al., 2006), which occupied 50.9\% and $29.8 \%$ of the area respectively. And there is approximately $5.5 \%$ yellow soil (Alfisols), 5.1\% purplish soil (Inceptisols) and 5.8\% regosol. The soil map of the area is shown in Figure 4 (a. K factor).

\section{Topography}

The study area is located at the juncture of two hills. The east and west of the county is enclosure by hills, and between hills there is a valley plain of the Puyang River. The east hills, Kuaiji hills, divide the Puyang River watershed and Cao'e River watershed, while the west hills, Longmen hills, divide the Puyang River watershed and Fuchun River watershed. The elevation of whole area is declined from north to south with the highest place at $1194.6 \mathrm{~m}$. The topography data were obtained from the DEM data which were from International Scientific \& Technical Data Mirror Site with the resolution of $30 \mathrm{~m}$.

\section{$R S$ data preparing}

A $73-\mathrm{km}^{2}$-reservoir in the county started to construct from 2013; it influenced the landscape and the local river system largely. So that we acquired the data until 2013, and sieved the data with cloud less than 5\%, and the time step was set to 5 to 10 years in order to examine the effect of urbanization. As a result, the data from 1984 to 2009 were chosen as the research data. 


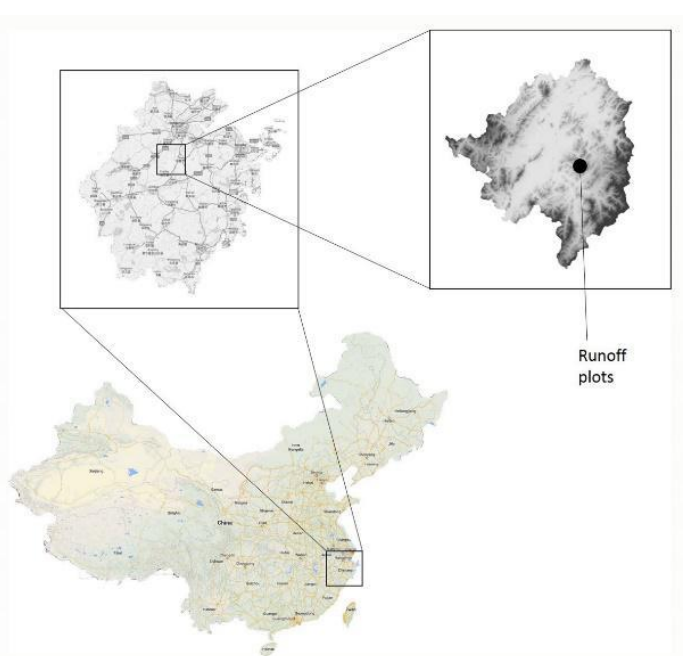

$\mathbf{a}$

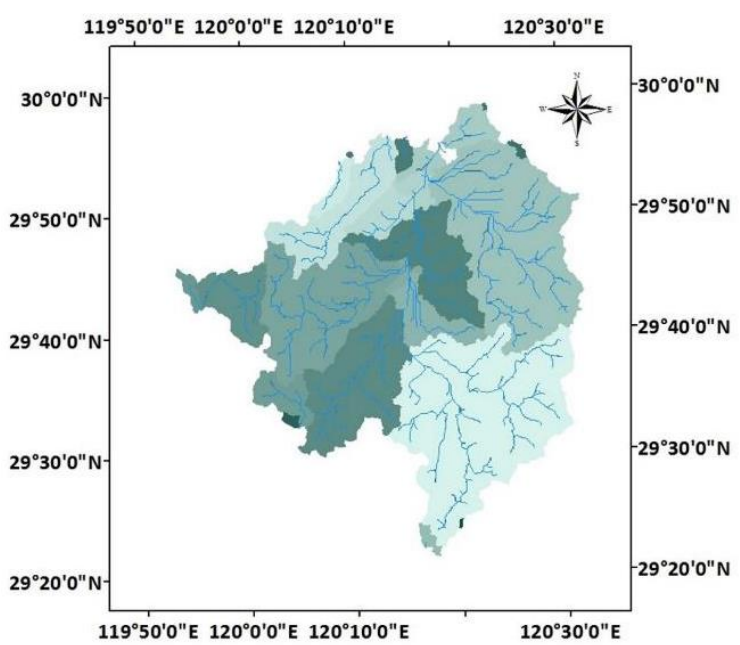

b

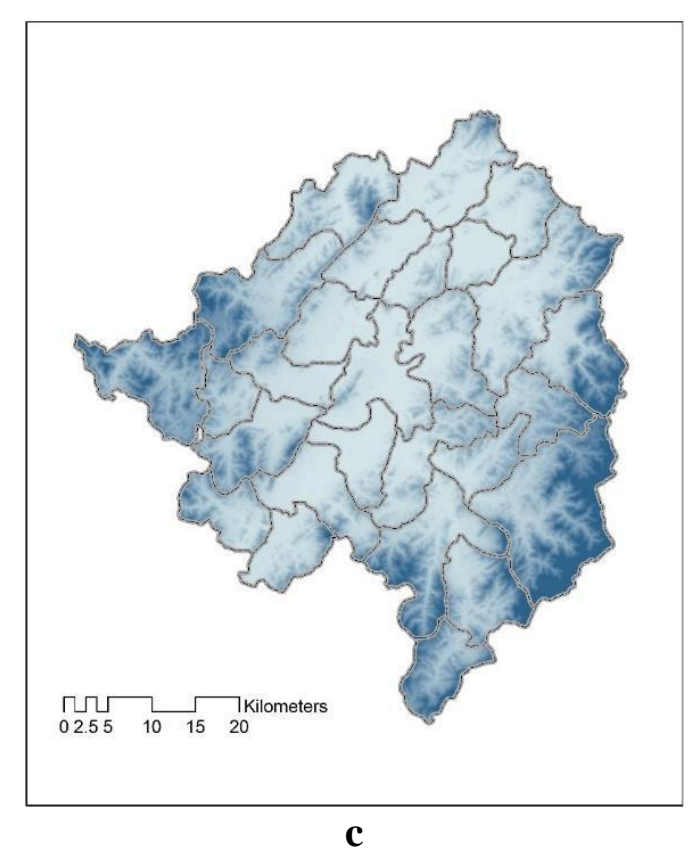

Figure 1. $\boldsymbol{a}$ Location of the study area, $\boldsymbol{b}$ the watersheds in the area, $\boldsymbol{c}$ administrative division of the area

Land use/cover data were classified from Landsat MMS image of the county for 1984, TM images for 1994, and ETM images for 2004 and 2009, all of which were obtained from Geospatial Data Cloud site, Computer Network Information Center, Chinese Academy of Sciences (http://www.gscloud.cn). The resolution was $30 \mathrm{~m}$ for TM and ETM images, and $80 \mathrm{~m}$ for MMS image. In this research, the land use types were mainly classified following Anderson level 1, which includes 1) Urban (including urban and built-up area), 2) Forest, 3) Agriculture (paddy land) 4) Agriculture (crop land), 5) bare land, and 6) water. As a result, there are 6 land use types in total in this study.

The reference land use data were land-use map of 1987 with scale of 1:300,000, map of 1991 with scale of 1:100,000, and map of 2005 with scale of 1:100,000. The classified results were also calibrated and revised by field verification. To verify the 
results, we randomly picked 50 points within the study area on the map, and went to the field to check the land use type. The correct number is 46 out of 50 .

\section{RUSLE}

The Revised Universal Soil Loss Equation (RUSLE) is a widely used empirical model for soil erosion estimation. It was originally proposed by Wischmeier and Smith (1965; Renard et al., 1991) in USA, known as universal soil loss equation (USLE). Since USLE was mainly based on the data from short and gentle slopes, it could not be applied in basins or watershed with complicated environments. Renard et al. (1997) improved the model to RUSLE by modifying the algorithm of factors, especially rainfall-runoff erosivity factor ( $\mathrm{R}$ factor), slope length and steepness factor (LS factor), and cover-manage factor ( $\mathrm{C}$ factor). The equation of the RUSLE is as follows (Eq. l):

$$
\mathrm{A}=\mathrm{R} \times \mathrm{K} \times \mathrm{LS} \times \mathrm{C} \times \mathrm{P}
$$

where $\mathrm{A}$ is average soil erosion amount per year $\left(\mathrm{Mg} \mathrm{ha}^{-1}\right.$ year $\left.{ }^{-1}\right), \mathrm{R}$ is the rainfallrunoff erosivity factor $\left(\mathrm{MJ} \mathrm{mm} \mathrm{ha}{ }^{-1}\right.$ year $\left.^{-1}\right), \mathrm{K}$ is the soil erodibility factor $\left(\mathrm{Mg} \mathrm{h}^{\mathrm{a}} \mathrm{MJ}^{-1}\right.$ $\mathrm{mm}^{-1}$ ), LS is topography factor ( $\mathrm{L}$ is slope length factor and $\mathrm{S}$ is slope steepness factor), $\mathrm{C}$ is cover-management factor, and $\mathrm{P}$ is support practice factor.

\section{$R$ factor}

$\mathrm{R}$ factor is used to quantify the rain-drop strike energy per year in the equation. There are several different algorithms to calculate $\mathrm{R}$ factor in using data in different precision, such as rain intensity in $30 \mathrm{~min}$, precipitation amount per day, or precipitation amount per month. In this research, we used the model developed by Xinbo et al. (2001) in the same area (in Zhejiang Province) to calculate the $\mathrm{R}$ factor. The model uses daily data of precipitation amount while considering the difference of rainfall intensity among different seasons in one year. The equation is as follows (Eq. 2):

$$
\mathrm{R}_{j}=a\left[1+b \sin \left(\frac{\pi}{12}(j-1)\right)\right] \sum_{i=1}^{\mathbb{\Phi}=1} P_{k j} \quad P_{k}>P_{0}
$$

where $\mathrm{R}_{j}$ is the $\mathrm{R}$ value of the $\mathrm{j}$ month; $P_{k}$ is the precipitation of the $\mathrm{k}$ day in the $\mathrm{j}$ month; $P_{0}$ is the threshold of precipitation value, only $P_{k}$ larger than $P_{0}$ is calculated in the equation, in this research, the value of $P_{0}$ is $12.7 \mathrm{~mm}$; a, b are parameters, according to Xinbo et al. (2001), based on the precipitation data from 1987 to 2000, a is 0.0043, b is 48.13. $R$ value of the whole year is the sum of every month's $R$ value.

Rainfall in the study area was interpolated from 19 rain gauge stations scattered in the Zhejiang Province in which 2 rain gauge stations were in the study area. The interpolation was conducted in using ordinary kriging method with spherical semivariogram model.

The result is as Figure $4 c$.

\section{Kfactor}

$\mathrm{K}$ factor is the indicator of the resistance of the soil to erosion by rainfall and runoff. It is mainly related to the physical properties of the soil, such as the particle 
composition, the porosity, and ratio of organic matter content. In this research, $\mathrm{K}$ factor was calculated using the equation developed by Sharpley and Williams (1990) in the Erosion-production impact calculator model (EPIC). The calculate equation is as follows (Eq. 3):

$$
\begin{aligned}
& \mathrm{K}= \\
& \frac{1}{7.6}\left(0.2+0.3 \cdot \exp \left(-0.0256 \operatorname{SAN}\left(1-\frac{S I L}{100}\right)\right)\right)\left(\frac{S I L}{C L A+S I L}\right)^{0.3}\left(1.0-\frac{0.250 M}{O M+\exp (3.72-2.950 M)}\right)(1.0- \\
& \left.\frac{0.7 S N}{S N+\exp (-5.51+22.95 M)}\right)
\end{aligned}
$$

where SN = 1.0 - SAN / 100; SAN, SIL, CLA, and OM are the percentage of sand, silt, clay and organic matter in the soil, respectively.

The data required to calculate $\mathrm{K}$ factor is obtained from the digital soil map of China, with the map scale 1:1,000,000. The result is as Figure $4 a$.

\section{LS factor}

LS factor is the indicator of the topography effect on soil loss. L factor quantifies the slope length effect while $S$ factor quantifies the effect of the slope steepness.

$\mathrm{S}$ factor (Eqs. 4-6) is use the algorithm developed by McCool et al. (1987) and revised by Liu et al. (1994):

$$
\begin{array}{cc}
\mathrm{S}=10 \times \sin \theta+0.03 & \theta<9 \% \\
\mathrm{~S}=16 \times \sin \theta-0.50 & \theta \geq 9 \% \\
\mathrm{~S}=21.91 \times \sin \theta-0.96 & \theta \geq 14 \%
\end{array}
$$

where $\theta$ is the slope gradient $(\%)$.

L factor was calculated by the method proposed by Desmet and Govers (1996), in which the $\mathrm{L}$ factor of one grid was determined by the contribute area of it (the grids surrounding it), the equation is as follows (Eq. 7):

$$
L_{i, j}=\frac{\left(A_{i, j-i n}+D^{2}\right)^{m+1}-A_{i, j-i n}^{m+1}}{D^{2} \times X_{i, j}^{m} \times 22.13^{m}}
$$

where $L_{i, j}$ is the $\mathrm{L}$ factor of $\operatorname{grid}(\mathrm{i}, \mathrm{j}), A_{i, j-i n}$ is the effective area which flow into $\operatorname{grid}(\mathrm{i}, \mathrm{j})$, $\mathrm{D}$ is the length of the grid, $\chi_{i, j}$ is the coefficient of $\operatorname{grid}(\mathrm{i}, \mathrm{j})$, the equation of $\chi_{i, j}$ is as follows $(E q .8)$ :

$$
\chi_{i, j}=\sin \left(\theta_{i, j}\right)+\cos \left(\theta_{i, j}\right)
$$

where $\theta_{i, j}$ is the slope of $\operatorname{grid}(\mathrm{i}, \mathrm{j}), \mathrm{m}$ is the slope length coefficient in original algorithm of $\mathrm{L}$ factor of RUSLE, the equation of $\mathrm{m}$ is as follows (Eqs. 9-10):

$$
\mathrm{m}=\frac{\beta}{\beta+1}
$$




$$
\beta=\frac{\left(\frac{\sin \theta}{0.0896}\right)}{3.0 \times(\sin \theta)^{0.8}+0.56}
$$

where $\theta_{i, j}$ is the slope of grid(i,j).

The algorithm was written in python for the ArcGIS. The result is as Figure $4 b$.

\section{C factor}

$\mathrm{C}$ factor is the surface coverage factor, which is used to describe the effect of surface coverage on the erosion. According to the definition, the value of $\mathrm{C}$ factor mainly depends on the size of the vegetation which control soil erosion, and it relates to the surface area's status, including surface roughness, the amount of contained water and the plant characteristics. The value of $\mathrm{C}$ factor ranges from 0 to 1 . Smoother the surface is, less the cover vegetation, closer the value is to 1 and vice versa.

The $\mathrm{C}$ factor calculation in this research was mainly based on the land-use type, referencing the value based on the research of Yang et al. (2003), as shown in Table 1.

Table 1. Value of $C$ factor and $P$ factor for the land-use types

\begin{tabular}{c|c|c}
\hline & C factor & P factor \\
\hline Water & 0.01 & 1 \\
Urban and built-up & 0.2 & 1 \\
Forest & 0.006 & 1 \\
Paddy land & 0.1 & 0.5 \\
Cropland & 0.5 & 0.5 \\
Bareland & 0.35 & 1 \\
\hline
\end{tabular}

\section{$P$ factor}

The support practice factor $\mathrm{P}$ represents the impact of support practice, such as contour hedgerows and stripping cropping, on average annual soil erosion. Different soil erosion prevention policy has a different $\mathrm{P}$ value. The more effective the practice is, the closer the $\mathrm{P}$ value is to 0 , and vice versa. At the same time, different land-use type also has a different $\mathrm{P}$ value. Due to limited available data, $\mathrm{P}$ value in this research was mostly determined by land-use type, which also is a common practice in the research using RUSLE. P value was calculated also based on the value suggested by Yang et al. (2003; Table 1).

The result of CP factor is as Figure $4 d$.

\section{CLUES}

\section{Land use transition}

To set scenarios and predict the future soil erosion, the Conversion and Land Use and its Effect (CLUE) model was used here to simulate the land use type in certain scenarios. CLUE model is a dynamic model to predict the future land use type with a 
spatial allocation module and a non-spatial land-use demand module (Verburg et al., 2002).

\section{Demand module}

Land use demand module is a relatively independent part in the CLUE model (Batisani and Yarnal, 2009). It calculates the change of areas for all land use type in an aggregate level. There are various alternative models for the demand module, ranging from extrapolation to social-economic model. In this research, grey model was chosen to extrapolate the future demand of all the land-use type. It is a method to do trend extrapolation. Compare to the least square method, grey model $(\operatorname{GM}(1,1))$, which based on the grey system theory (Kayacan et al., 2010), would generate a trend line with a gentler gradient. The detail of $\operatorname{GM}(1,1)$ can be found in previous studies such as Kayacan et al. (2010).

Demand prediction was based on the continuous 11-year (from 2000 to 2010) interpreted RS data. There are 7 land-use types in total, including water, forest, paddy land, crop land, urban and built-up land, and bare land. The area of each type was calculated by multiplying the calculated percentage with the total area of Zhuji County.

\section{Model variables selection}

Land-use map of 2001 was reclassified into 7 maps with 7 land-use types, respectively, and 2001 was set as the initial year. Each land-use type was a dependent variable in step-wise logistic regression. In this research, we selected 10 explanatory independent variables for the 7 land-use types based on the previous researches (Table 2; Podmanicky et al., 2011; Verburg et al., 2002; Batisani and Yarnal, 2009). However, in the binary logistic regression analysis, the $5^{\text {th }}$ factor, the distance from $\mathrm{CBD}$, the beta value was too small (less than $10^{-7}$ ). As a result, it was deleted from the factors. Beta values and constants for CLUE model are shown in Table 3.

The variables for each land-use type and the result of logistic regression are shown in Table 3.

Table 2. Total explanatory variables of land-use types

\begin{tabular}{c|c|c}
\hline No. & Variables & Unit \\
\hline 1 & GDP & Yuan $/ \mathrm{km} 2$ \\
2 & Population density & Inhabitants $/ \mathrm{km} 2$ \\
3 & Distance from river & $\mathrm{m}$ \\
4 & Distance from road & $\mathrm{m}$ \\
5 & Distance from CBD & $\mathrm{m}$ \\
6 & Slope & Degree \\
7 & Elevation & $\mathrm{m}$ \\
8 & Aspect & $\%$ \\
9 & Soil organic content & $*$ \\
10 & Area & Derived from DEM (8 directions $)$ \\
\hline
\end{tabular}

*Category variable 
Table 3. Beta value for variables of each land-use type

\begin{tabular}{c|c|c|c|c|c|c}
\hline Variables No. & Water & Urban and built-up & Forest & Paddy land & Cropland & Bare land \\
\hline 1 & - & -0.0093 & 0.0075 & -0.0133 & 0.0019 & 0.0152 \\
2 & -0.0005 & -0.0003 & 0.0004 & 0.0005 & -0.0006 & 0.0005 \\
3 & - & -0.0001 & 0.0001 & -0.0002 & 0.0000 & - \\
4 & -0.0001 & -0.0002 & 0.0001 & -0.0001 & 0.0000 & -0.0001 \\
6 & 0.0039 & 0.0059 & -0.0072 & 0.0096 & 0.0024 & 0.0041 \\
7 & 0.0005 & -0.0005 & 0.0010 & -0.0016 & -0.0009 & 0.0012 \\
8 & - & 0.0003 & -0.0002 & 0.0002 & -0.0001 & -0.0007 \\
9 & 0.0296 & -0.0616 & 0.0443 & -0.0119 & -0.0221 & 0.0208 \\
10 & -0.0153 & -0.0350 & 0.0307 & -0.0508 & -0.0038 & 0.0327 \\
Constant & -3.6301 & -0.8707 & -0.7393 & -1.5464 & -0.9422 & -7.3565 \\
\hline
\end{tabular}

The variable No. is as shown in Table 2

\section{Scenario setting}

According to RUSLE, soil erosion risk is mainly determined by topography, soil erodibility, precipitation in the area, land use/cover types and management measures. Since the natural conditions hardly change in a short period, in this research, only land use types were recognized as the reason cause the changing of the erosion risk.

In order to assess the soil erosion risk in the 2020, the following scenarios were set:

- Scenario 1: the county develops as the land-use planning of 2006-2020. According to the planning, the built-up area will be less than $15.33 \%$.

- Scenario 2: the county develops as the current trend, which is simulated by $\operatorname{GM}(1,1)$. The built-up area will occupy $18.86 \%$ of the whole county in this scenario.

- Scenario 3: the county will not control the city development; the built-up area will reach $25 \%$ till 2020 .

In these scenarios, R factor was calculated using the data of 2009, C and P factor were calculated depending on the land use types in different scenarios.

\section{Verification}

The data of 2013 was chosen to verify the prediction of CLUEs model. Scenario 1 was chosen to be the data to compare. The results of 2013 simulated in CLUEs is shown as Figure $2 a$, and the interpreted data is shown as Figure $2 b$. We randomly pick 500 points at same locations in these two figures in ArcGIS, and compare the values. The result shows the correct rate is $87.2 \%(436 / 500)$.

\section{Analysis of the impact of highway}

In this research, we selected a highway started building in 1999 and completed in 2004 to study the impact of road on erosion. The location of the highway was shown in Figure 3. Buffer zone analysis was used to analyze the influence of the highway on 
erosion risk. To examine the influence distance of the highway, 20 buffer zones were set, from $60 \mathrm{~m}$ to $1200 \mathrm{~m}$ with step of $60 \mathrm{~m}$.

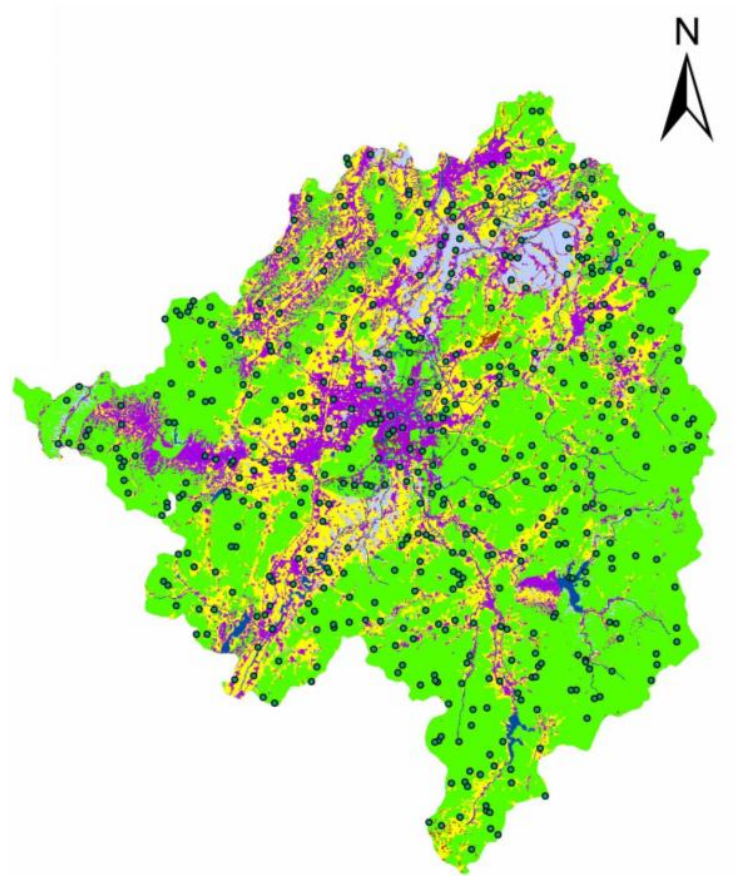

$\mathbf{a}$

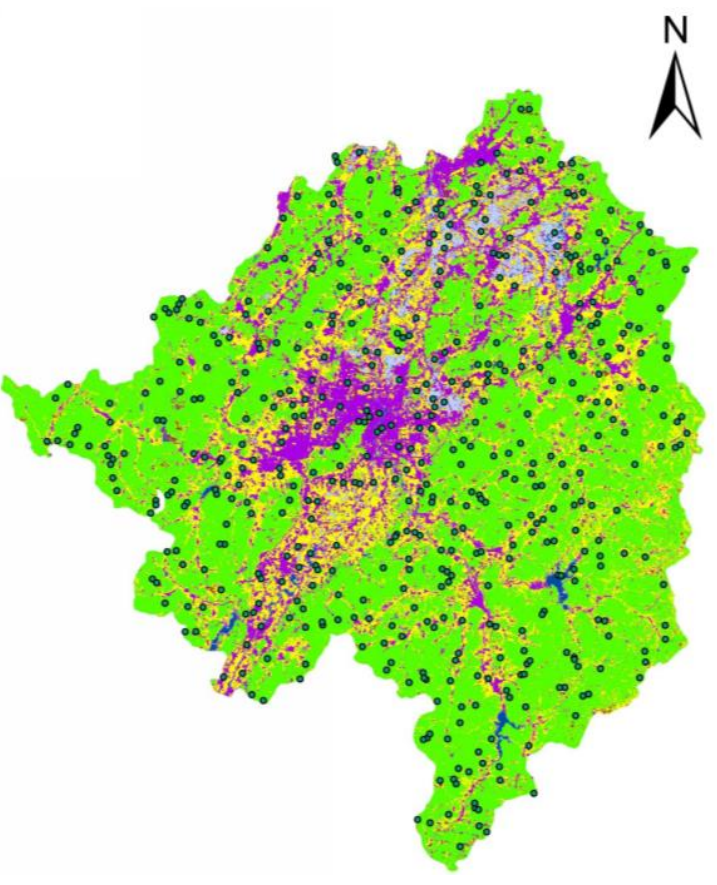

b

Figure 2. Compare of the simulation and interpreted land use type of 2013. a Simulation, $\boldsymbol{b}$ interpreted

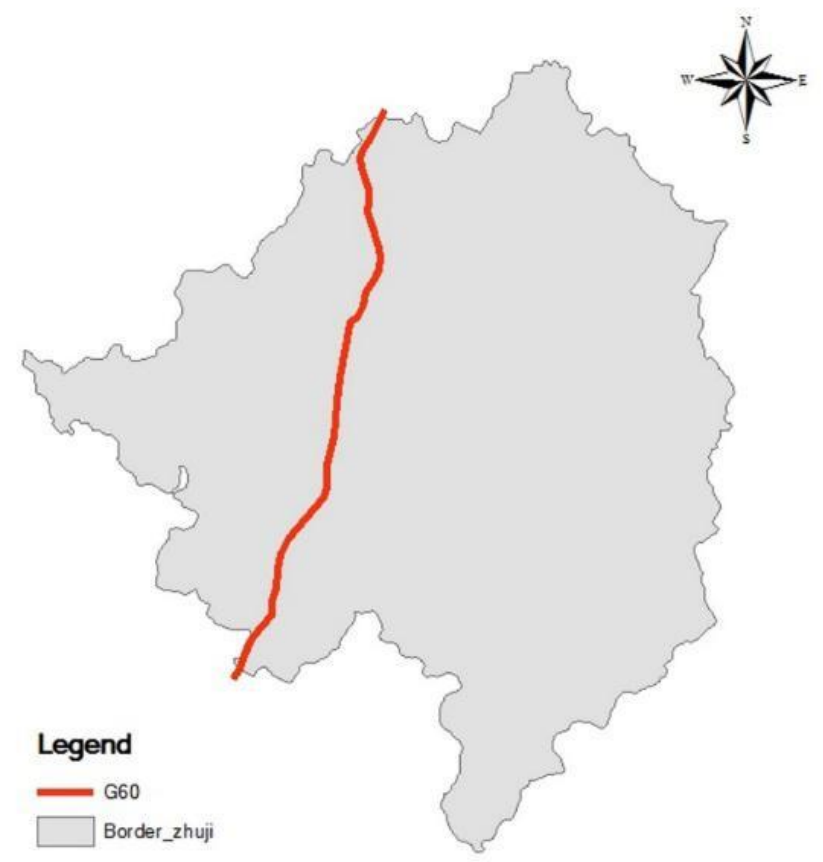

Figure 3. The location of the highway G60 


\section{Results}

\section{The results of RUSLE factors}

Figure 4 shows the results of the factors of RUSLE.

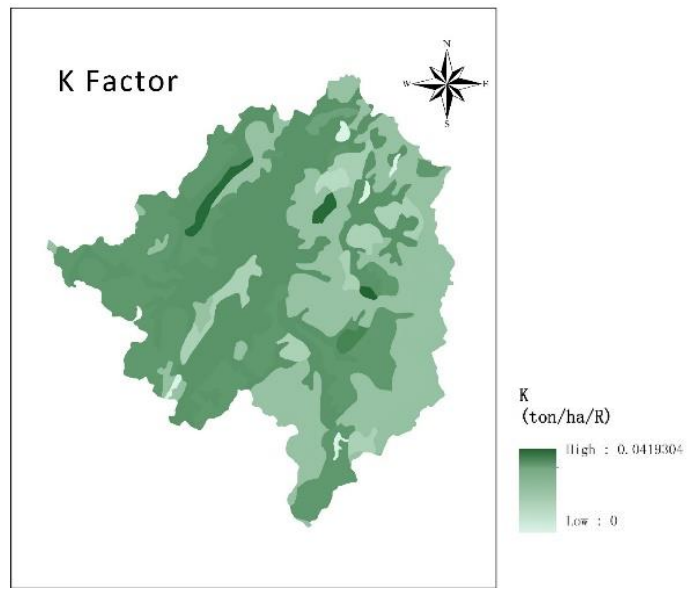

$\mathbf{a}$

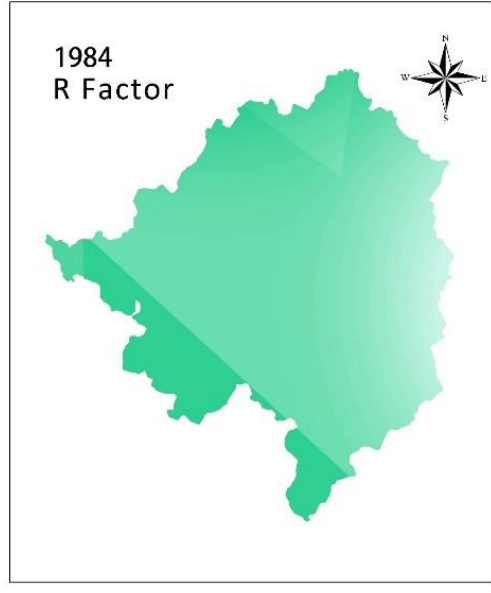

c1

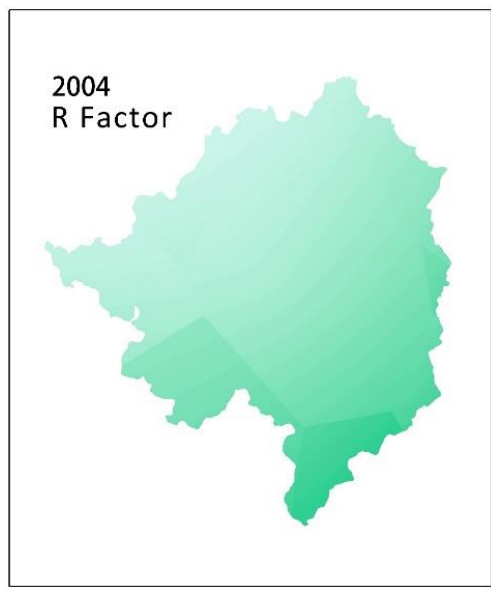

c3

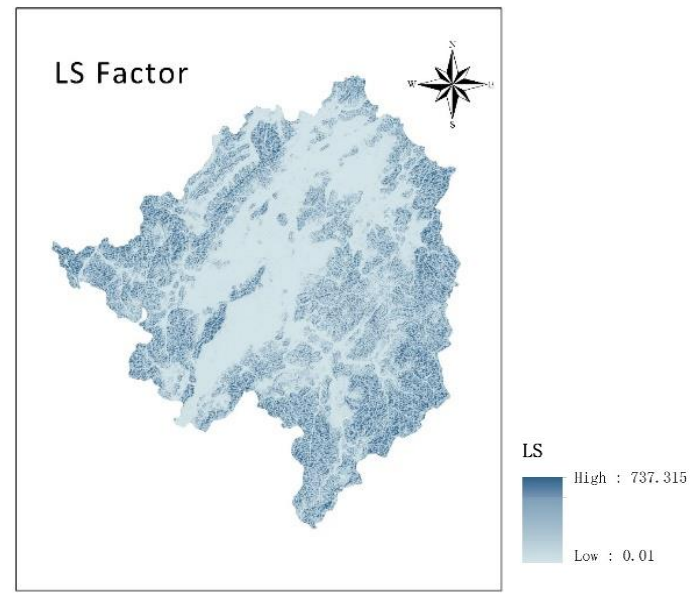

b

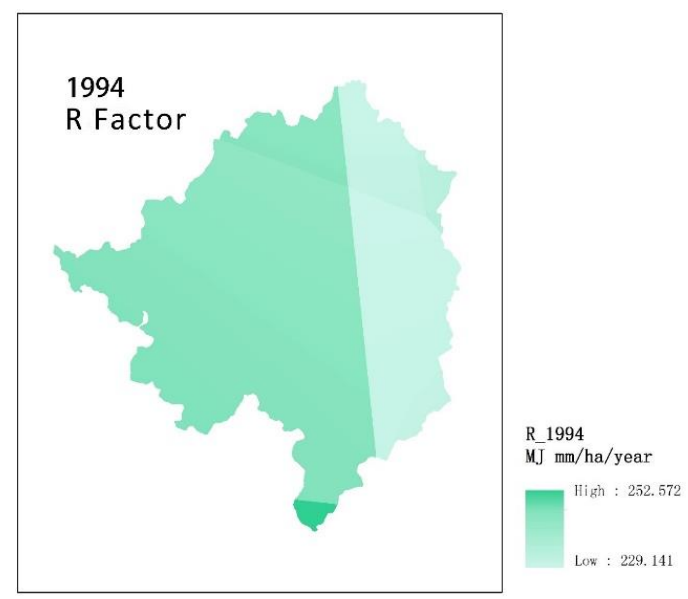

c2

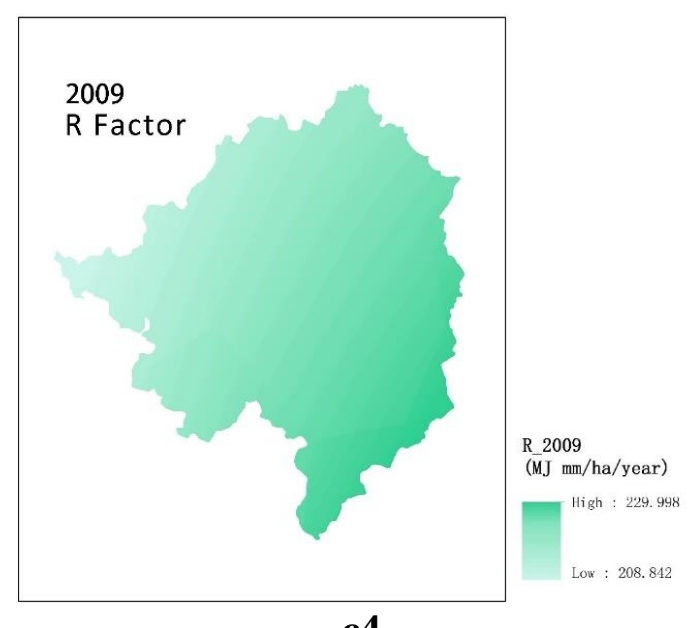

c4 


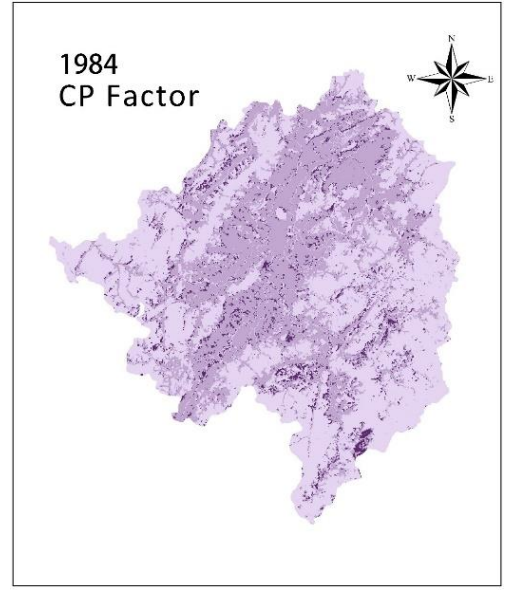

d1

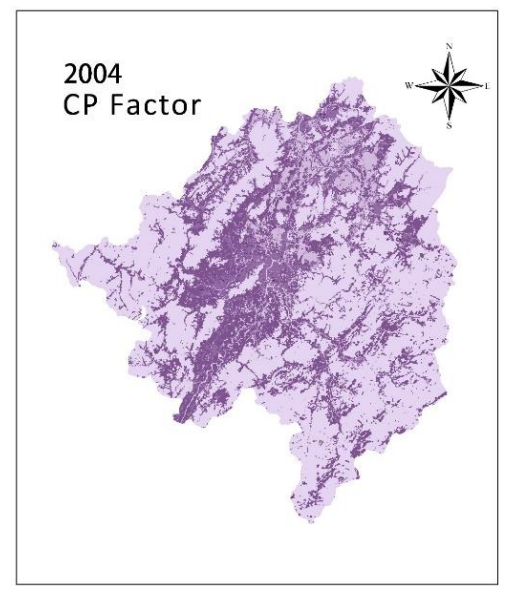

d3

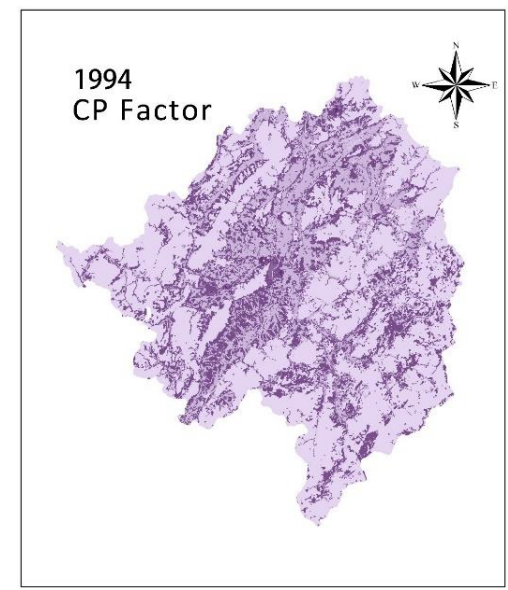

d2

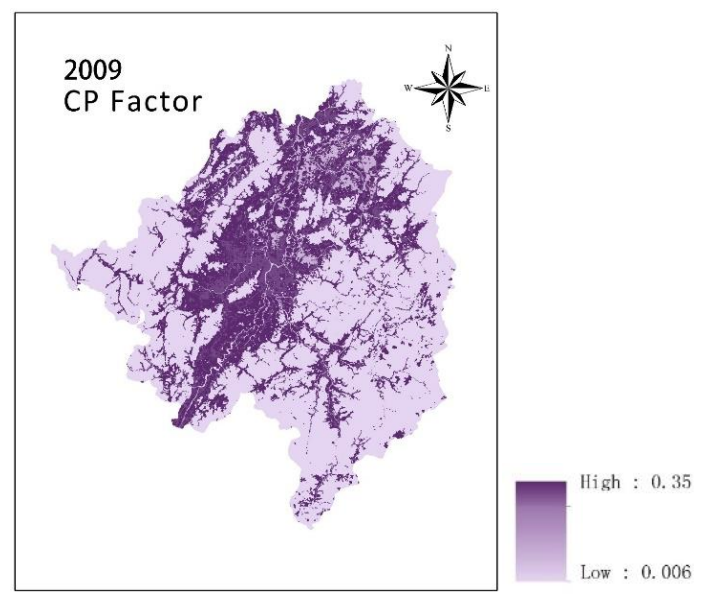

d4

Figure 4. The factors for RUSLE. a K factor; $\boldsymbol{b}$ LS factor; $\boldsymbol{c 1 - 4} R$ factor for 4 years; $\boldsymbol{d 1 - 4} C P$ factor for 4 years

\section{Soil erosion change over 1984-2009}

Figure 5 shows the result of RUSLE of four different years: 1984, 1994, 2004 and 2009. The maps show the erosion amount of each grid with area of 0.09 ha per grid. Compare to the map of 1984, there are more erosion in 1994, 2004 and 2009. And the maximum erosion amount per grid is highest in 1994 (938.43 ton $\mathrm{hm}^{-2} \mathrm{a}^{-1}$ ). Erosion amount was increasing from 1984 to 1994 in the southeast part of the county, and increasing from 2004 to 2009 in the northwest part of the county.

\section{The change of erosion risk over 1984-2009}

The results in Figure 5 was calculated using rainfall data of correspondent year. However, the total rainfall was different from year to year with 2004 being the year with extremely low level (Fig. 4c). To eliminate the difference introduced by rainfall, the rainfall data of 2009, which was close to the average value of past 25 years from 1984-2009, was used to calculate the erosion risk for all years. The result was shown in Figure 6. The erosion risk was divided into 5 ranks based on the erosion amount: 


$$
-867-
$$

tolerable (less than 1 ton/ha/year), low (1-10 ton/ha/year), medium (10-50 ton/ha/year), high (50-100 ton/ha/year) and severe (more than 100 ton/ha/year).

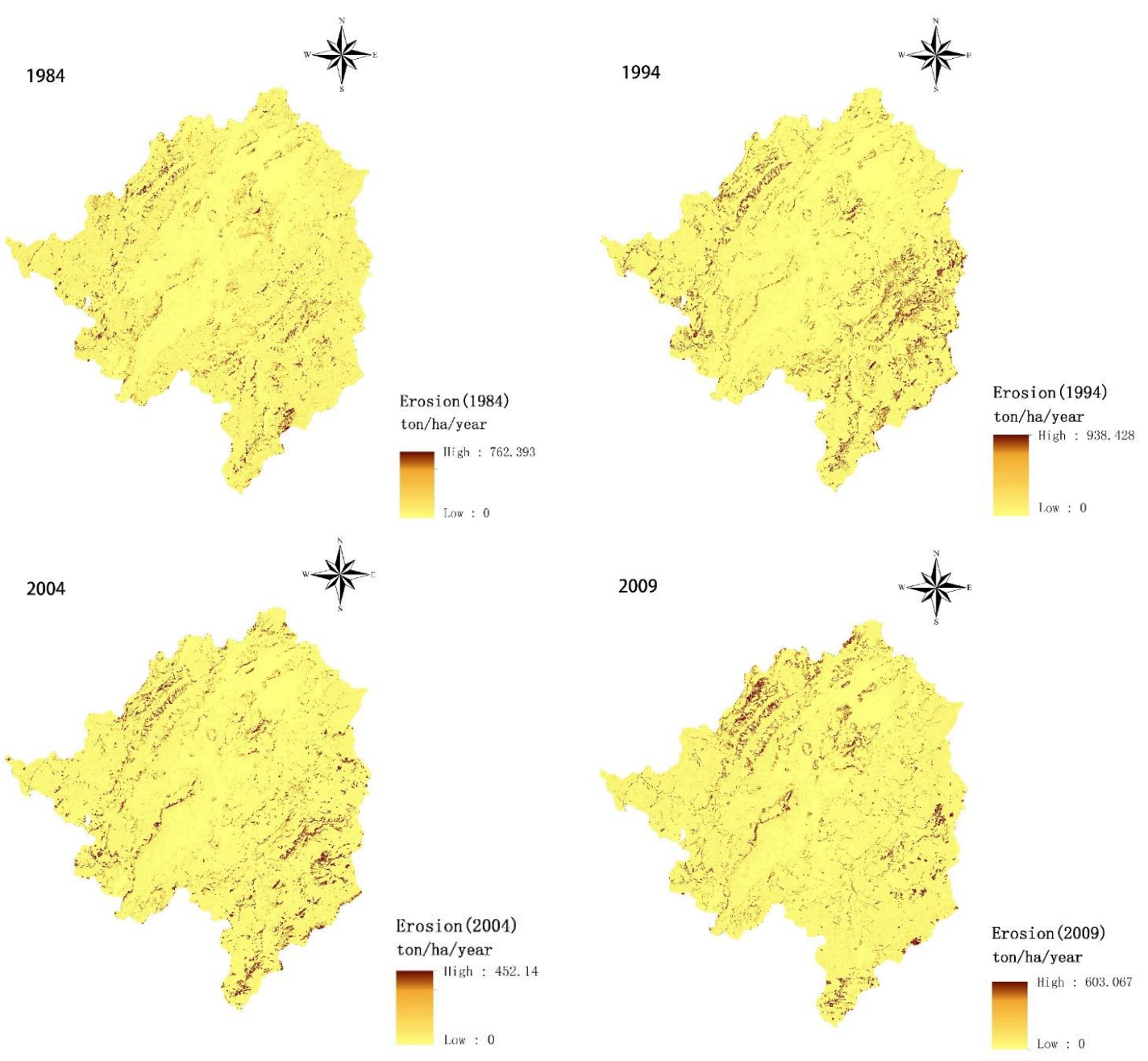

Figure 5. Soil erosion risk in 1984, 1994, 2004 and 2009 (with actual precipitation data)
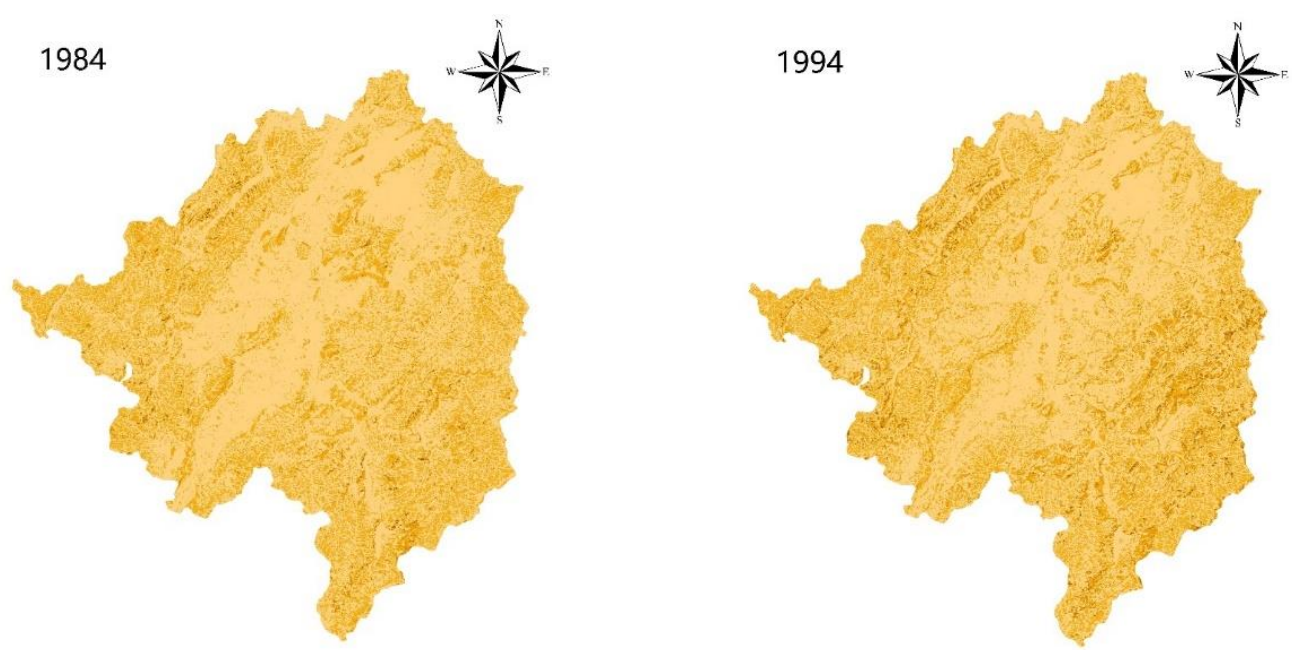

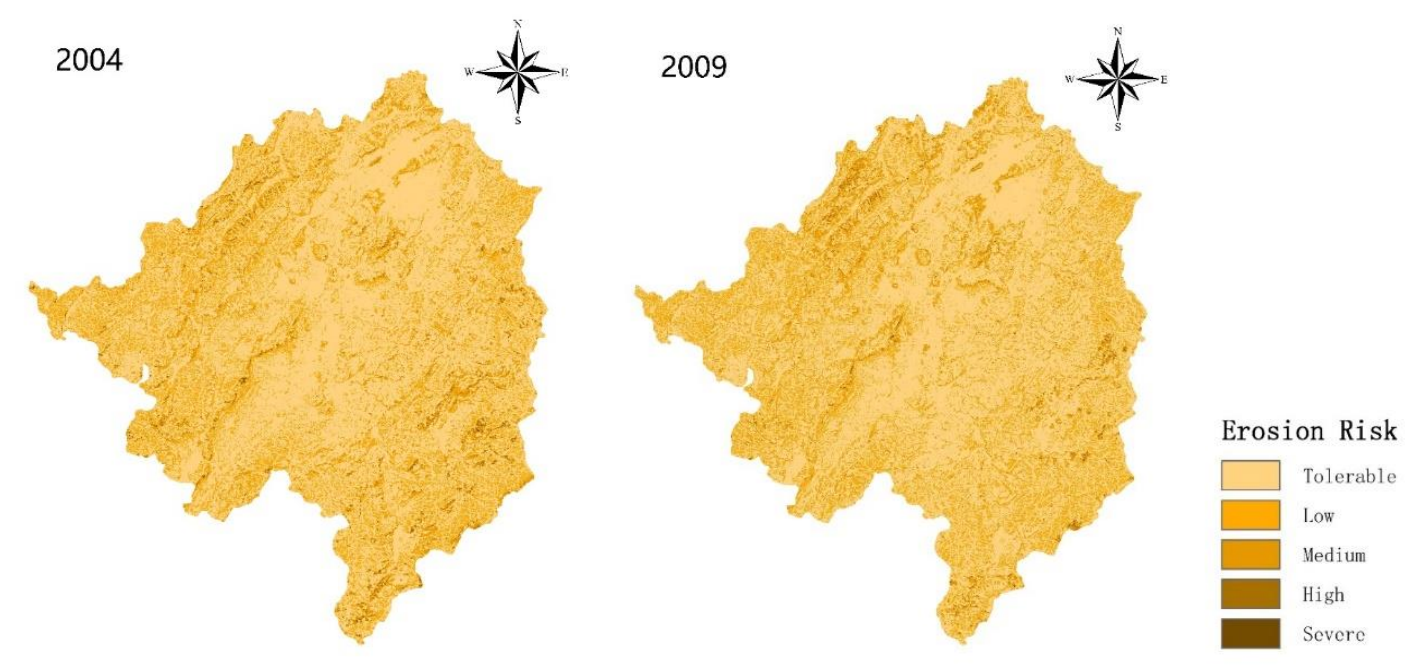

Figure 6. Soil erosion risk in 1984, 1994, 2004 and 2009 (with precipitation data of 2009)

As is shown in Table 4, area with tolerable and severe erosion risk was decreasing, while area with low erosion risk was increasing. And the change of the area with medium and high erosion risk shows no clear trend.

Table 4. Soil erosion risk level and the max value

\begin{tabular}{c|c|c|c|c|c|c}
\hline Year & Tolerable & Low & Medium & High & Severe & $\begin{array}{c}\text { Max value } \\
\left(\text { ton } \mathbf{h m}^{-2} \mathbf{a}^{-1}\right)\end{array}$ \\
\hline 1984 & $71.57 \%$ & $25.20 \%$ & $2.74 \%$ & $0.41 \%$ & $0.08 \%$ & 777.69 \\
1994 & $68.12 \%$ & $25.02 \%$ & $5.78 \%$ & $0.90 \%$ & $0.18 \%$ & 819.74 \\
2004 & $68.01 \%$ & $25.61 \%$ & $5.37 \%$ & $0.88 \%$ & $0.13 \%$ & 620.59 \\
2009 & $67.58 \%$ & $26.09 \%$ & $5.32 \%$ & $0.92 \%$ & $0.10 \%$ & 603.07 \\
\hline
\end{tabular}

\section{Scenario analysis}

The land use maps from 2009 to 2020 were simulated using CLUEs model, and 2020-year-landuse maps in 3 different scenarios were shown in Figure 7. Due to the government restriction on turning cropland and paddy land into urban and built-up land, and with a big proportion of forest in study area, the urban and built-up land was mainly transformed from forest in all these 3 scenarios. The plain in the middle of the county was mostly occupied by agriculture land. As a result, the urban and built-up land was hardly increased in the middle. As shown in Figure 7, during the simulation period from 2009-2020, the urban and built-up land increased around lakes at the southeast and the west of the county, as well as the small plain located at the northwest area.

Since the topography in locations of newly urbanization part is mainly hills with high-value LS factor, once the vegetation is removed, the erosion risk will increase largely. Figure 8 shows the erosion risk under 3 different scenarios. Comparing the result of 3 scenarios, it is obvious that the erosion risk is mainly increased at the newly urbanized area, especially for the increase of the risk at high and severe level. Table 5 shows the data which compares the ratios of the erosion risk levels in 2009 and different 
scenarios. It is clearly that as the area of the urban and built-up land increase, the ratios of high and severe soil erosion risk levels increase, and area with medium erosion risk decreases. The trend appears slightly different with the data in period from 1984 to 2009.

Table 5. Percentages of soil erosion risk levels and the max erosion risk values

\begin{tabular}{c|c|c|c|c|c|c}
\hline & Tolerable & Low & Medium & High & Severe & $\begin{array}{c}\text { Max value } \\
\left(\mathbf{t o n ~ h m ~}^{-2} \mathbf{a}^{-1}\right)\end{array}$ \\
\hline 2009 & $67.58 \%$ & $26.09 \%$ & $5.32 \%$ & $0.92 \%$ & $0.10 \%$ & 603.07 \\
Scenario_1 & $67.92 \%$ & $24.59 \%$ & $6.20 \%$ & $1.09 \%$ & $0.20 \%$ & 833.87 \\
Scenario_2 & $66.99 \%$ & $24.38 \%$ & $7.09 \%$ & $1.30 \%$ & $0.24 \%$ & 933.24 \\
Scenario_3 & $62.80 \%$ & $24.12 \%$ & $10.69 \%$ & $2.00 \%$ & $0.38 \%$ & 936.31 \\
\hline
\end{tabular}
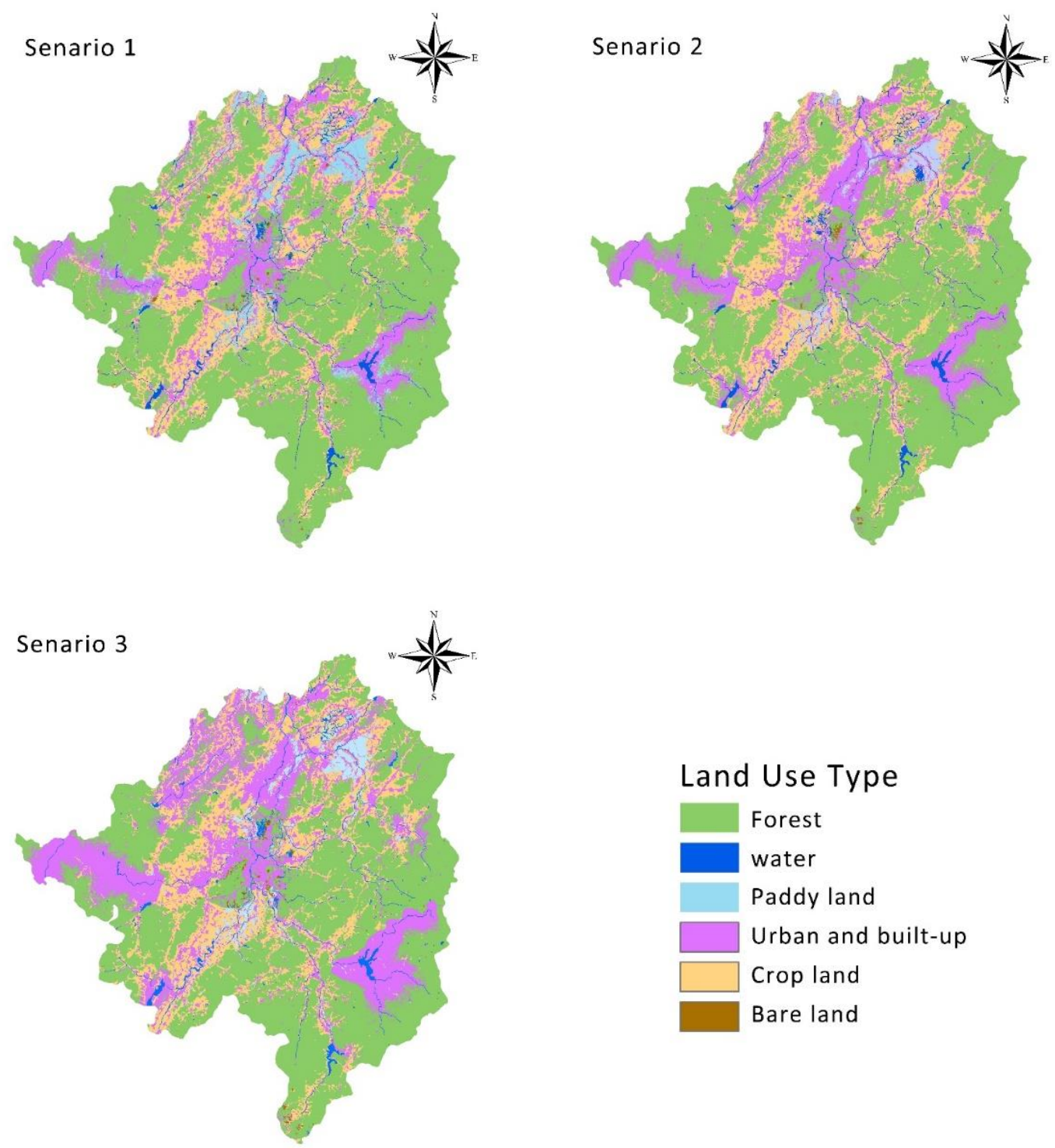

Figure 7. Land use type of 3 scenarios in 2020 

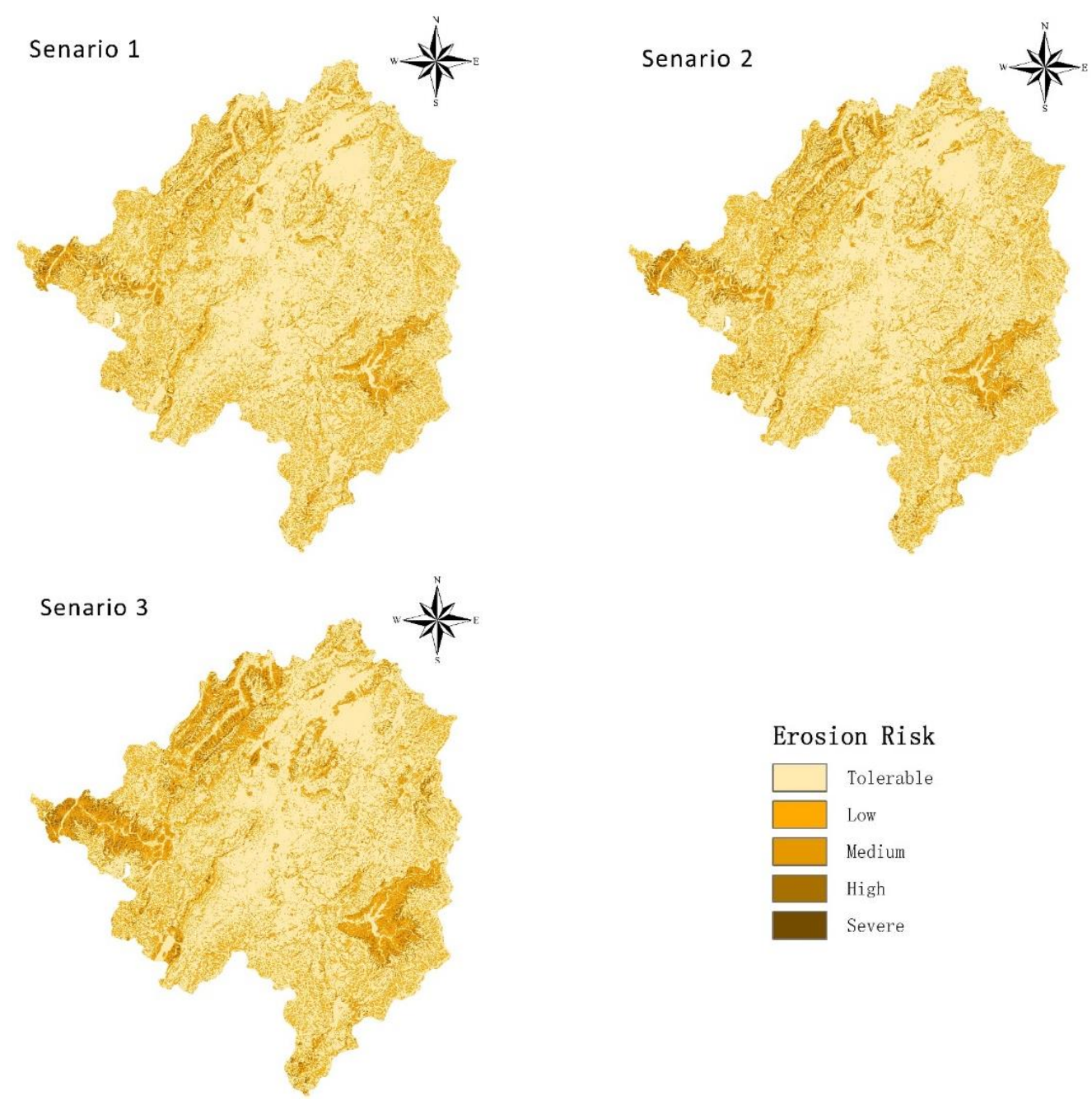

Erosion Risk

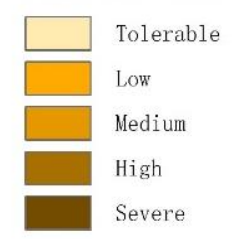

Figure 8. Soil erosion risk of 3 scenarios in 2020

\section{Discussion}

\section{Relationship between erosion and built-up area}

Wolman (1967) pointed out that during the construction period, the erosion amount would increase in situ, and reach to a higher value than that at the condition with natural vegetation cover. Biggs et al. (2010) studied the urban border from 1938 to 2002, and suggested that even a long period after urban and built-up, the area would be still with a high erosion rate. White and Greer (2006) had studied the relationship between urbanization and the hydrology in the watershed in California. The result showed that the runoff volume was increasing during urbanization, both for annual average and dryseason runoff volume, and the peak value was increasing as well. It indicates that the increase of impermeable surface area would affect the regional hydrological process. And the erosion would be affected by the change of the hydrology.

The process of the urbanization during 1984 to 2009 in Zhuji county is shown as Figure 9. Because the middle and north of the county are mainly plains, the urbanization in those areas was faster than the rest of the county. From 1984 to 2009, the total urban and built-up area was increasing from $0.43 \%$ (1984) to $10.95 \%$ (2009). 


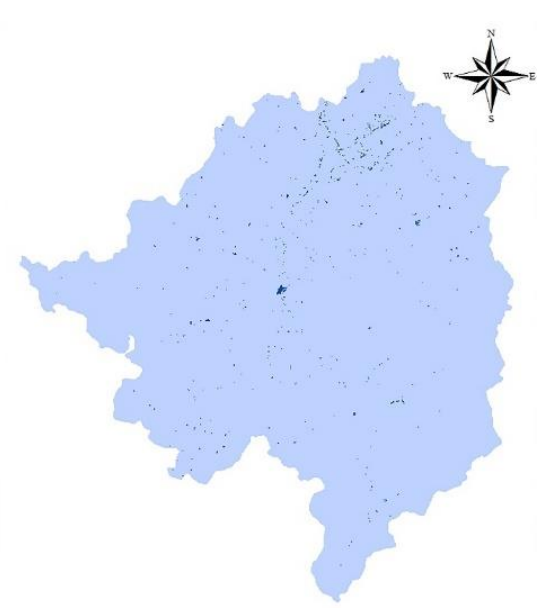

$\mathbf{a}$

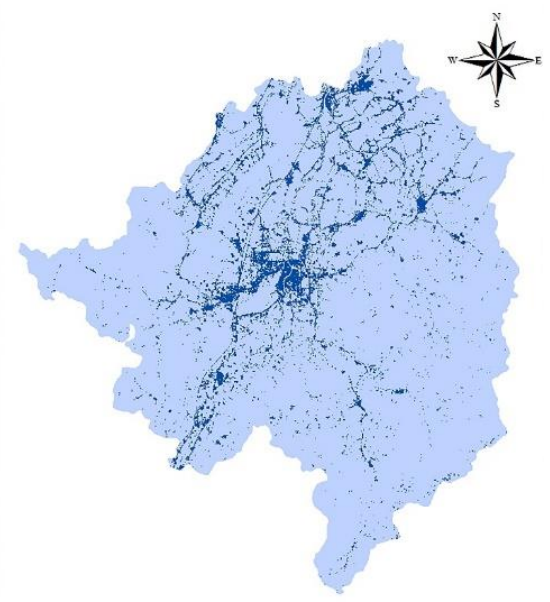

c

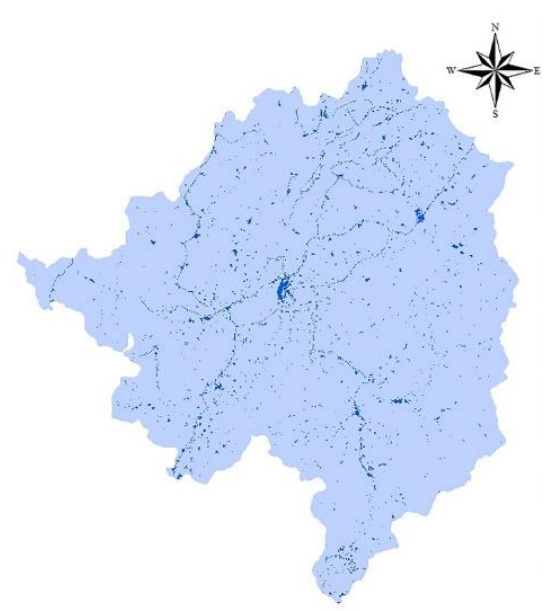

b

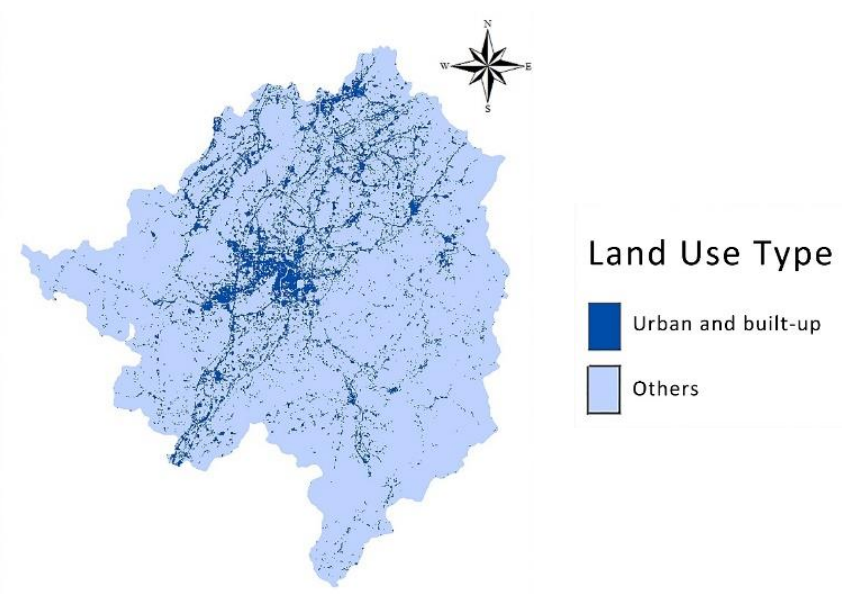

d

Figure 9. The process of urbanization from 1984 to 2009. a 1984, b 1994, c 2004, d 2009

As shown in Figure 6, during 1984 to 1994, the erosion risk increased in the southeast of the county since the percentage of cropland transformed by forest was increasing in this district. With further economic development, the ratio of agriculture in the GDP gradually decreased, leading to more cropland transformed back to forest in the Southeast. As a result, the erosion risk was decreasing in the southeast from 1994 to 2009. In 2009, the erosion risk in the southeast hilly area was obviously lower than that of 1994. In contrast, the erosion risk in the north and northwest was higher than that of 1984, driven by the drastic urbanization from 1984-2009 in these areas.

Table 4 shows that the area with tolerable erosion risk level was decreasing from 1984-2009, while the area of low erosion risk level was increasing. In stages perspective, from 1984 to 1994, the area with erosion risk level above medium was increasing sharply; from 1994 to 2009, the area with low erosion risk was increasing, while the area with tolerable erosion risk was decreasing.

Analyzed by the $\mathrm{CP}$ value, as the increasing of forest area and decreasing of agriculture area, the erosion risk should be decreasing in the whole area of Zhuji county. However, the data shows that the area with low erosion risk was increasing, though the maximum erosion risk value is decreasing. It indicated that the urbanize process mainly 
invade forest area, and though the decreasing area of the agriculture land partly transformed to forest, the other part transformed to urban and built-up area, all of these lead to the rising of the erosion risk in the whole area. Table 6 shows that the area with severe erosion risk level in urban and built-up area is increasing, while it in crop land is decreasing from 1994 to 2009.

The scenario analysis shows that, the ratios of areas with high and severe erosion levels are increasing with the ratio of the built-up area, as well as the extreme value of the erosion risk. However, the changing trends are different between scenario analysis from 2010 to 2020 and real data from 1984 to 2009. This is probably because of the different way of land use change. During the 1986 to 2009, the urban and built-up land was increased mainly on the plain in the middle of the county, transforming from agriculture land including crop land and paddy land. In the simulation period from 2010 to 2020, driven by the policy of prohibition in occupying the agriculture land, the urban and built-up land is mainly transformed from forest located in the hilly area in the west and the east parts of the county, which lead to the various value of the LS factor in the calculation.

Table 6. Land-use types with severe erosion risk level

\begin{tabular}{c|c|c|c|c}
\hline \multirow{2}{*}{ Land use type } & \multicolumn{4}{|c}{ Areas of Land use type $\left(\mathbf{h m}^{-\mathbf{2}}\right)$} \\
\cline { 2 - 5 } & $\mathbf{1 9 8 4}$ & $\mathbf{1 9 9 4}$ & $\mathbf{2 0 0 4}$ & $\mathbf{2 0 0 9}$ \\
\hline Paddy land & 1.8 & 0 & 0 & 0 \\
Cropland & 1346.4 & 4062.6 & 3586.5 & 1749.6 \\
Urban and built-up & 0 & 53.1 & 120.6 & 266.4 \\
Bare land & 486 & 53.1 & 227.7 & 206.1 \\
\hline
\end{tabular}

Because the study area was located in the south-eastern part of China, the precipitation is plentiful for the growth of plant, which will decrease the soil erosion risk. The erosion risk is low in the area as a total. The trend from 1984 to 2009 is mainly showed in the decrease of the tolerable soil erosion risk level. Combining the data of the scenario analysis, the tolerable soil erosion risk area is decreasing during the urban area is increasing (Fig. 10).

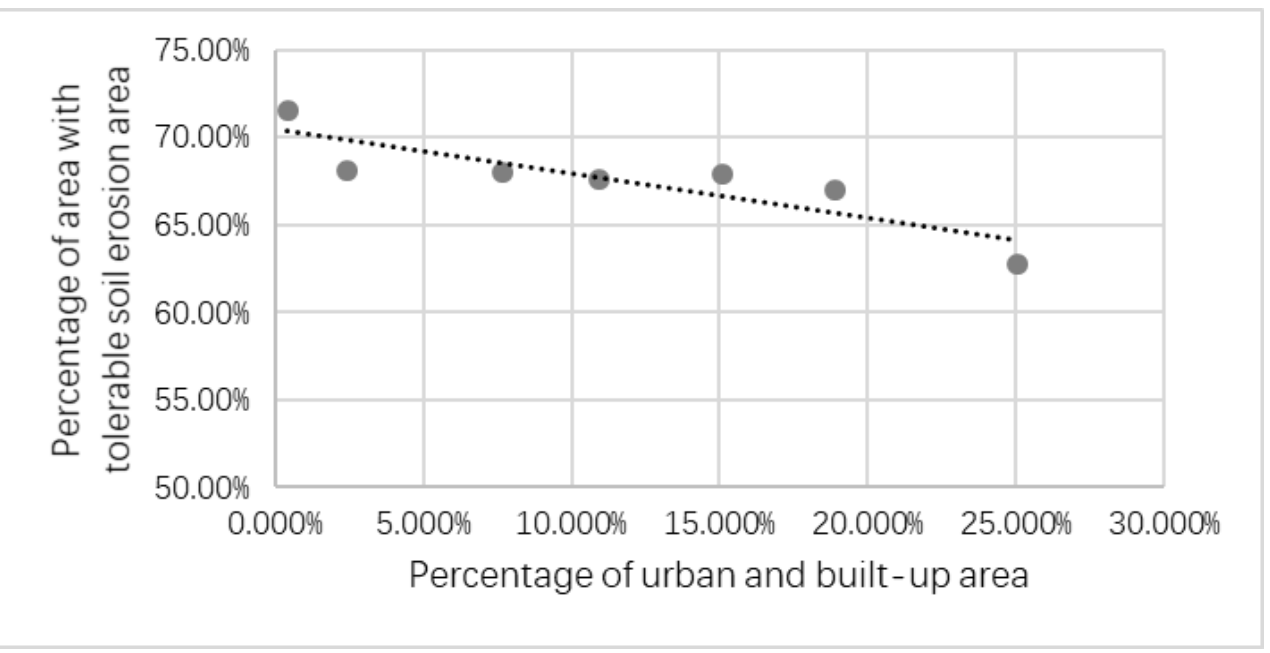

Figure 10. The relationship between tolerable soil erosion area and urban and built-up area 


\section{The effect of the highway}

Roads are an indispensable part of urbanization. It also influences erosion seriously. Building road will influence the stability of the soil on side slope (Grace III, 1999). The construction sites with unpaved road surface as well as the cut areas are the sources of the erosion (Kalainesan et al., 2009). The spoil deposits of the road construction would also cause severe soil erosion (Dong et al., 2012). The increase of the impervious surface and runoff through the culvert of the highway will increase the erosion risk. Meanwhile, the urban and built-up area and human activities usually increase along the road, which will further increase the erosion risk.

As the Figure 11 shows, the overall trends of erosion risk along the distance from the highway in tolerable, low and medium level were almost kept the same for 1999, 2004 and 2009. However, overall tolerable level \% was highest in 1999, while the low and medium level increased in 2004 and 2009. The trends of high and severe erosion risk levels were different between before and after the highway construction, especially for the severe level. As Figure 1le shows, the severe level percentage in 2004 was much higher compared to that of 1999 before the road construction, and the percentage began to decrease when the distance from the highway reached $540 \mathrm{~m}$. The curve of the high erosion risk level shows the similar trend and becomes stable when the distance meets $540 \mathrm{~m}$.
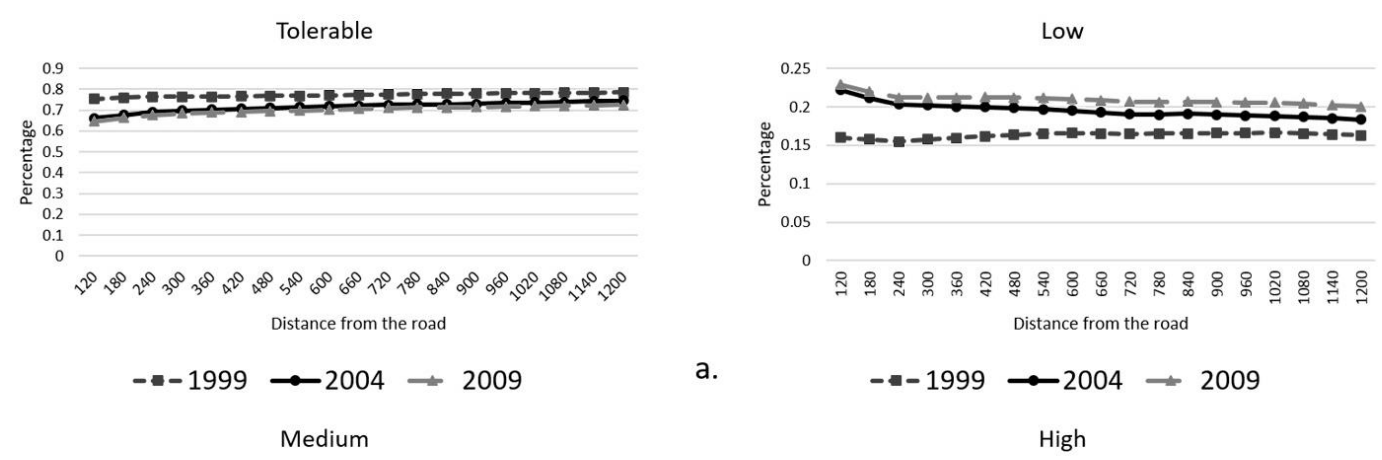

a.
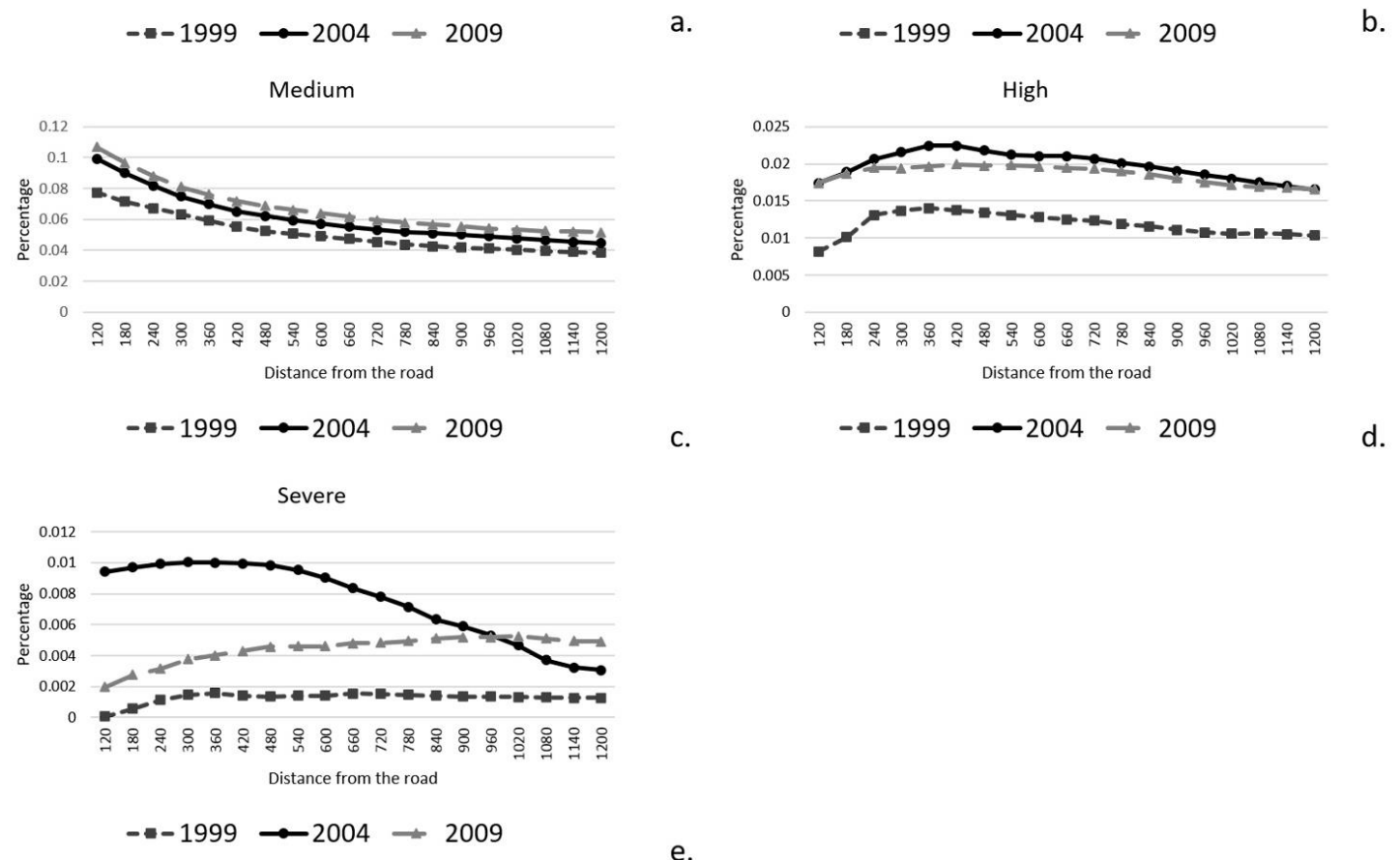

C.

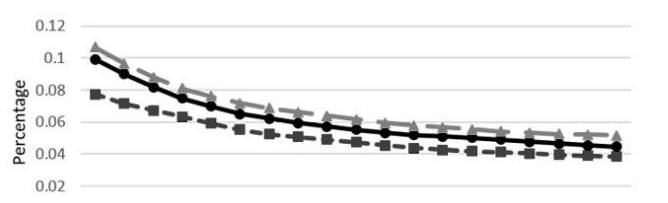

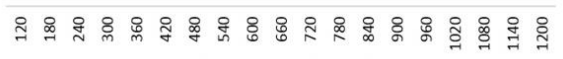

Distance from the road

d.

Figure 11. The erosion risk in different buffer zones of highway G60. a Tolerable level; $\boldsymbol{b}$ low level; $\boldsymbol{c}$ medium level; $\boldsymbol{d}$ high level; $\boldsymbol{e}$ severe level 
Meanwhile, the construction of road would accelerate the economic development nearby and increase the urban and built-up area percentage, which could potentially further increase the erosion risk. As the data in 2009 shown, 5 years after the highway completed, erosion risk became more severe than that in 1999 as a whole. In detail, compare to 1999, the percentage of tolerable level decreased, but all the other levels increased, which means the road effect on soil erosion continued after the construction completed.

Figure 12 shows the percentage of the urban and built-up land in the buffer zones in 1999, 2003 and 2009. It indicates that the urban and built-up area increased after the highway was completed. After the highway constructed, the percentage of the urban and built-up area became stable when the distance from the road farther than $420 \mathrm{~m}$.

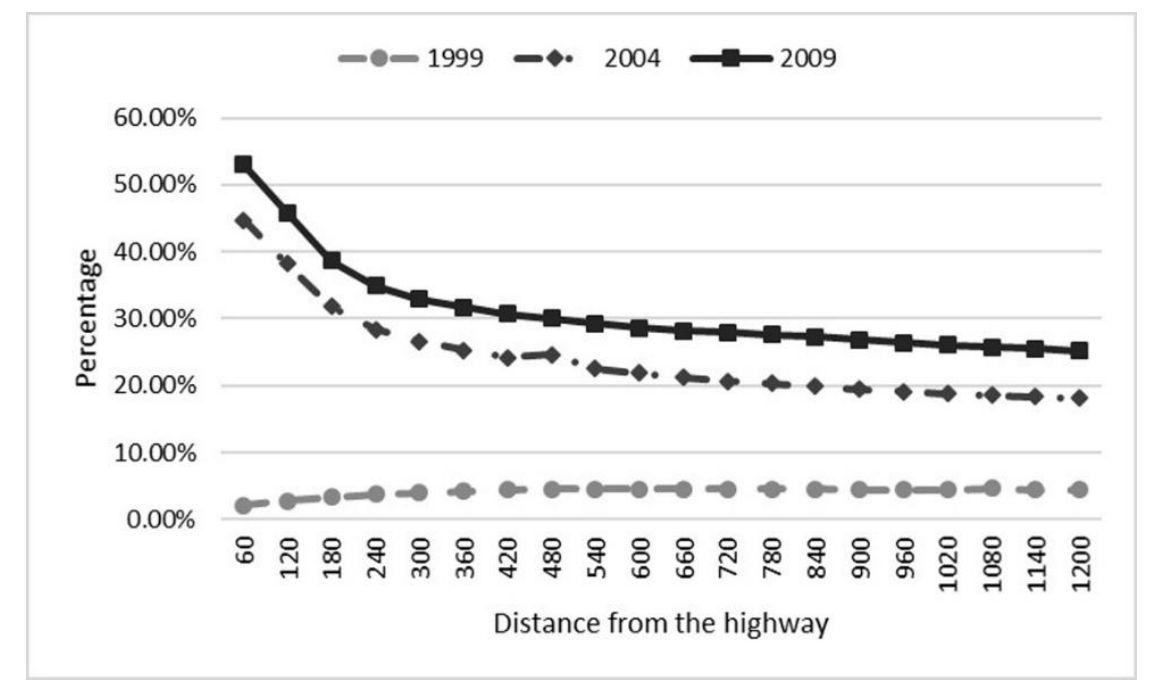

Figure 12. The percentage of the urban and built-up area in the buffer zones

\section{Effect of hydrology change}

Urbanization will also change the land use pattern in the catchment. The increased impervious surface and the drainage network will influence the hydrology in the peri urban area significantly (Rodriguez et al., 2013). And peak surface runoff values will increase with the urban and built-up area. Hammer (1972) found that the runoff value in the cross-sectional area in Piedmont Pennsylvania was 3.8 times larger than those in rural area. And naturally, the hydrology change affects the sediment yield and changes the erosion risk (Henshaw and Booth, 2000).

Simulating the hydrology change by urbanization is a key step to estimate the soil erosion risk. RUSLE was used in this research is because of its convenience in acquiring data as well as it has been already widely applied in the world. In this research, the process of the hydrology was mainly simulated by the algorithm of $\mathrm{L}$ factor combined with the change of land use types.

We also monitored the hydrological change at the main river (Puyang River) in the study area to examine the effect of the hydrological change on the erosion during the urbanization (from 2000 to 2010) (Fig. 13). Chart b in Figure 13 shows that before 2005 the maximum daily runoff was roughly in the same trend as the maximum daily rainfall. But after 2006, the pattern did not hold any more. Even maximum daily rainfall 
was low, the maximum daily runoff still kept in a high level. And the relationship between annual runoff and erosion is also similar to daily data. Compared to the data in 2005 , though the annual runoff decreased in 2006, the annual erosion increased.

According to the previous studies (Rodriguez et al., 2013; Hammer, 1972; Henshaw and Booth, 2000), as the urbanization proceeding, the surface runoff should be increasing, however, the data does not show this trend clearly. This maybe because of the location of the monitor station. The station is located in the centre of the county, which is the centre of the urbanization area, it cannot show the change of the runoff and erosion in whole watershed.

Because hydrological change caused by the change of impervious surface was not fully simulated here and the micro topography changed by constructions was kind of hided by the $30-\mathrm{m}$ resolution, the effect of the urban and built-up area increasing was still not fully estimated. It should be studied in future research.
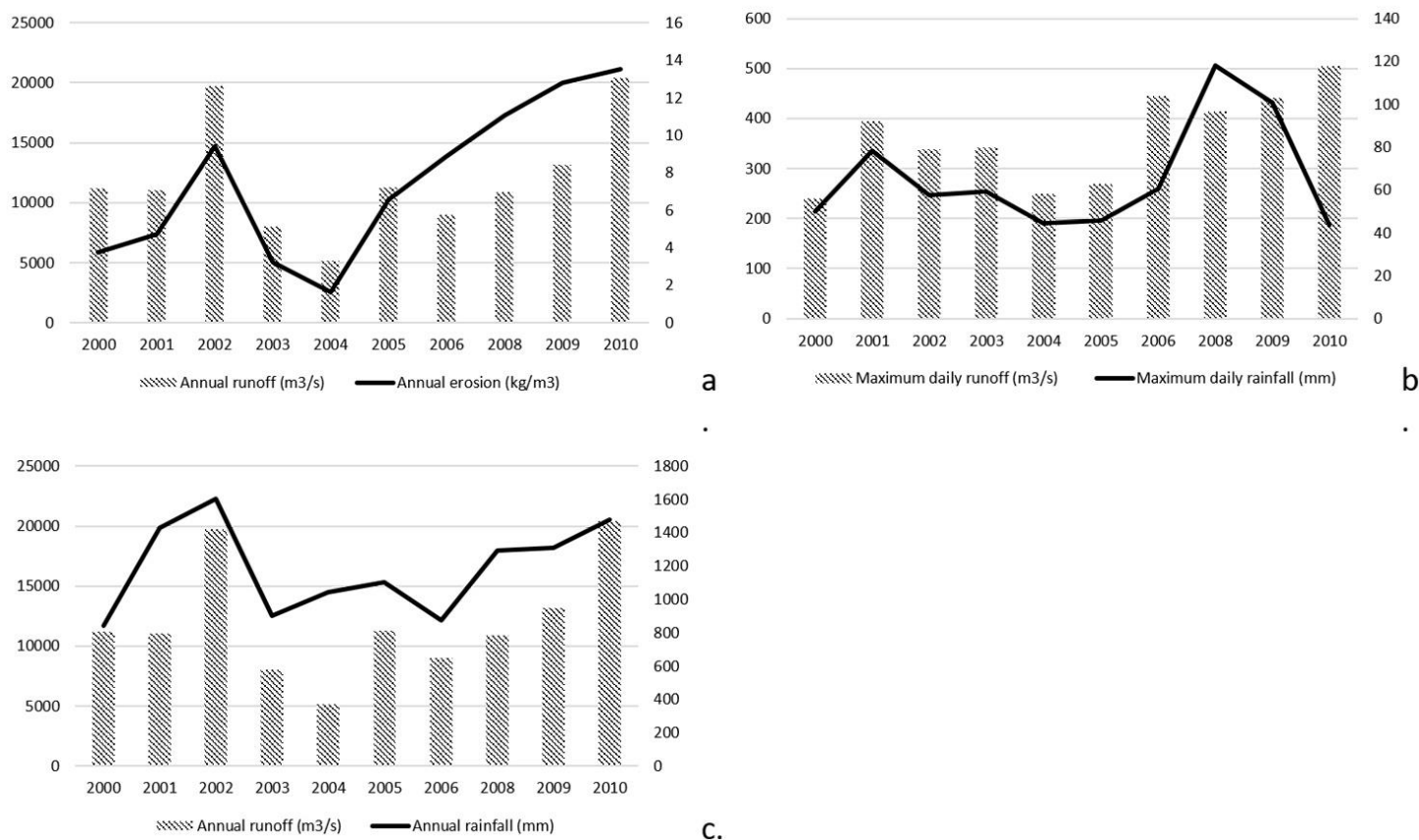

Figure 13. Rainfall and runoff. $\boldsymbol{a}$ annual runoff and annual erosion; $\boldsymbol{b}$ maximum daily runoff and maximum daily rainfall; $\boldsymbol{c}$ annual runoff and annual rainfall; $\boldsymbol{d}$ the percentage of the urban and built-up area

\section{Conclusion}

This research used the RS data to analyze the land use types from 1984 to 2009 of Zhuji County, estimate the erosion risk by RUSLE, and found the area with high and severe erosion risk was increasing (from $3.23 \%$ to $6.34 \%$ ) and the area with tolerable soil erosion risk was decreasing (from $71.57 \%$ to $67.58 \%$ ) while the built-up area was increasing from $0.43 \%$ to $10.95 \%$.

Comparing the 3 scenarios in 2020 which simulated by CLUE model, we found that Scenario 1, because of the least urban and built-up area (15.33\%), has the lowest erosion risk. Since the simulation considering the government policy to protect the agriculture land particularly, the urban and built-up area was mainly transformed from forest in hilly area during the simulation. Transforming forest into urban and built-up 
area lead to a higher the erosion risk than urbanizing in plain area. And the analysis of the highway impact also showed that the soil erosion risk positively correlated with the urban and built-up area. The result indicates that controlling the urban area can help manage the erosion risk. Considering the erosion risk, if people have to expand the urban and built-up area, the plain would be a better choice than the hilly area. How to balance the erosion risk and the preservation of agriculture land needs to be further studied.

In this research, the effect of hydrology change was mainly simulated by the algorithm of L factor combined with the land use types (CP factor), which reflect the effect of the impervious surface area change. However, the micro topography changed by constructions was not considered here. It needs further research for more accurate estimation.

Acknowledgements. The remote sensing data set is provided by Geospatial Data Cloud site, Computer Network Information Center, Chinese Academy of Sciences. (http://www.gscloud.cn). Thanks to the local apartment of land and resources for the reference land use data and the erosion data. A special expression of gratitude goes to the different counterparts for their support such as nuclear agricultural science research institute, Zhejiang University and Shaoxing academy of agricultural sciences. Finally, we would like to thank the reviewers for their comments on this paper.

\section{REFERENCES}

[1] Akhalkatsi, M., Otte, A., Togonidze, N., Bragvadze, T., Asanidze, Z., Arabuli, G., Chikhelidze, N., Mazanishvili, L. (2017): Agrobiodiversity and genetic erosion of crop varieties and plant resources in the Central Great Caucasus. - Annals of Agrarian Science 15(1): 11-16.

[2] Arnold, C. L., Gibbons, C. J. (1996): Impervious surface coverage: the emergence of a key environmental indicator. - Journal of the American Planning Association 62(2): 243258.

[3] Barbera, E., Curro, C., Valenti, G. (2010): A hyperbolic model for the effects of urbanization on air pollution. - Applied Mathematical Modelling 34(8): 2192-2202.

[4] Basile, P. A., Riccardi, G. A., Zimmermann, E. D., Stenta, H. R. (2010): Simulation of erosion-deposition processes at basin scale by a physically-based mathematical model. International Journal of Sediment Research 25(2): 91-109.

[5] Batisani, N., Yarnal, B. (2009): Urban expansion in Centre County, Pennsylvania: spatial dynamics and landscape transformations. - Applied Geography 29(2): 235-249.

[6] Beskow, S., Mello, C. R., Norton, L. D., Curi, N., Viola, M. R., Avanzi, J. C. (2009): Soil erosion prediction in the Grande River Basin, Brazil using distributed modeling. - Catena 79(1): 49-59.

[7] Biggs, T. W., Atkinson, E., Powell, R., Ojeda-Revah, L. (2010): Land cover following rapid urbanization on the US-Mexico border: implications for conceptual models of urban watershed processes. - Landscape and Urban Planning 96(2): 78-87.

[8] Boix-Fayos, C., de Vente, J., Albaladejo, J., Martínez-Mena, M. (2009): Soil carbon erosion and stock as affected by land use changes at the catchment scale in Mediterranean ecosystems. - Agriculture, Ecosystems \& Environment 133(1-2): 75-85.

[9] Boongaling, C. G. K., Faustino-Eslava, D. V., Lansigan, F. P. (2018): Modeling land use change impacts on hydrology and the use of landscape metrics as tools for watershed management: The case of an ungauged catchment in the Philippines. - Land Use Policy 72: $116-128$. 
[10] Chen, H., Oguchi, T., Wu, P. (2017): Assessment for soil loss by using a scheme of alterative sub-models based on the RUSLE in a Karst Basin of Southwest China. Journal of Integrative Agriculture 16(2): 377-388.

[11] Chen, J. (2007): Rapid urbanization in China: A real challenge to soil protection and food security. - Catena 69(1): 1-15.

[12] De Oña, J., Osorio, F., Garcia, P. A. (2009): Assessing the effects of using compostsludge mixtures to reduce erosion in road embankments. - Journal of Hazardous Materials 164(2-3): 1257-1265.

[13] Deckers, J., Driessen, P., Nachtergaele, F., Spaargaren, O. (2006): World Reference Base for Soil Resources. - In: Lal, R. (ed.) Encyclopedia of Soil Science. 2nd Ed. CRC Press, Boca Raton, FL, pp. 1918-1923.

[14] Desmet, P., Govers, G. (1996): A GIS procedure for automatically calculating the USLE LS factor on topographically complex landscape units. - Journal of Soil and Water Conservation 51(5): 427-433.

[15] Dong, J., Zhang, K., Guo, Z. (2012): Runoff and soil erosion from highway construction spoil deposits: A rainfall simulation study. - Transportation Research Part D: Transport and Environment 17(1): 8-14.

[16] García-Ruiz, J. M. (2010): The effects of land uses on soil erosion in Spain: A review. Catena 81(1): 1-11.

[17] Grace III, J. M. (1999): Erosion control techniques on forest road cutslopes and fillslopes in North Alabama. - Transportation Research Record: Journal of the Transportation Research Board 1652(1): 227-234.

[18] Guo, X., Wang, Z., Ru-liang, Z. (2001): Study on temporal distribution of rainfall erosicity and daily rainfall erosivity model in red soil area of Zhejiang (in Chinese). Journal of Soil and Water Conservation 15(3): 35-37.

[19] Hammer, T. R. (1972): Stream channel enlargement due to urbanization. - Water Resources Research 8(6): 1530-1540.

[20] Henshaw, P. C., Booth, D. B. (2000): Natural restabilization of stream channels in urban watersheds. - JAWRA Journal of the American Water Resources Association 36(6): 1219-1236.

[21] Kalainesan, S., Neufeld, R. D., Quimpo, R., Yodnane, P. (2009): Sedimentation basin performance at highway construction sites. - Journal of Environmental Management 90(2): 838-849.

[22] Kayacan, E., Ulutas, B., Kaynak, O. (2010): Grey system theory-based models in time series prediction. - Expert Systems with Applications 37(2): 1784-1789.

[23] Lewis, L. A., Verstraeten, G., Zhu, H. (2005): RUSLE applied in a GIS framework: Calculating the LS factor and deriving homogeneous patches for estimating soil loss. International Journal of Geographical Information Science 19(7): 809-829.

[24] Liu, B., Nearing, M., Risse, L. (1994): Slope gradient effects on soil loss for steep slopes. - Transactions of the ASAE 37(6): 1835-1840.

[25] McCool, D., Brown, L., Foster, G., Mutchler, C., Meyer, L. (1987): Revised slope steepness factor for the Universal Soil Loss Equation. - Transactions of the ASAE 30(5): 1387-1396.

[26] Napoli, M., Cecchi, S., Orlandini, S., Mugnai, G., Zanchi, C. A. (2016): Simulation of field-measured soil loss in Mediterranean hilly areas (Chianti, Italy) with RUSLE. Catena 145(246-256.

[27] Op de Hipt, F., Diekkrüger, B., Steup, G., Yira, Y., Hoffmann, T., Rode, M. (2018): Modeling the impact of climate change on water resources and soil erosion in a tropical catchment in Burkina Faso, West Africa. - Catena 163(63-77.

[28] OSD OSSD (1998): Keys to Soil Taxonomy.

[29] Ostovari, Y., Ghorbani-Dashtaki, S., Bahrami, H. A., Naderi, M., Dematte, J. A. M. (2017): Soil loss estimation using RUSLE model, GIS and remote sensing techniques: a 
case study from the Dembecha Watershed, Northwestern Ethiopia. - Geoderma Regional 11: $28-36$.

[30] Ouyang, W., Hao, F., Skidmore, A. K., Toxopeus, A. G. (2010): Soil erosion and sediment yield and their relationships with vegetation cover in upper stream of the Yellow River. - Science of The Total Environment 409(2): 396-403.

[31] Park, S., Oh, C., Jeon, S., Jung, H., Choi, C. (2011): Soil erosion risk in Korean watersheds, assessed using the revised universal soil loss equation. - Journal of Hydrology 399(3-4): 263-273.

[32] Podmanicky, L., Balázs, K., Belényesi, M., Centeri, C., Kristóf, D., Kohlheb, N. (2011): Modelling soil quality changes in Europe. An impact assessment of land use change on soil quality in Europe. - Ecological Indicators 11(1): 4-15.

[33] Qin, W., Guo, Q., Cao, W., Yin, Z., Yan, Q., Shan, Z., Zheng, F. (2018): A new RUSLE slope length factor and its application to soil erosion assessment in a Loess Plateau watershed. - Soil and Tillage Research 182(10-24.

[34] Renard, K. G., Foster, G. R., Weesies, G. A., Porter, J. P. (1991): RUSLE: Revised universal soil loss equation. - Journal of Soil and Water Conservation 46(1): 30-33.

[35] Renard, K. G., Foster, G. R., Weesies, G. A., McCool, D., Yoder, D. (1997): Predicting Soil Erosion by Water: A Guide to Conservation Planning with the Revised Universal Soil Loss Equation (RUSLE). Agriculture Handbook 703. - USDA, Washington.

[36] Rodriguez, F., Bocher, E., Chancibault, K. (2013): Terrain representation impact on periurban catchment morphological properties. - Journal of Hydrology 485(0): 54-67.

[37] Sharpley, A. N., Williams, J. R. (1990): EPIC-erosion/productivity impact calculator: 1. Model documentation. - Technical Bulletin-United States Department of Agriculture 1768 Pt 1.

[38] Stastical Bureal of Zhuji City (2017): Statistical Bulletin of National Economic and Social Development of Zhuji City. - National Bureau of Statistics of China, Beijing.

[39] Thomas, J., Joseph, S., Thrivikramji, K. P. (2018): Estimation of soil erosion in a rain shadow river basin in the southern Western Ghats, India using RUSLE and transport limited sediment delivery function. - International Soil and Water Conservation Research 6(2): 111-122.

[40] Trenouth, W. R., Gharabaghi, B. (2015): Event-based design tool for construction site erosion and sediment controls. - Journal of Hydrology 528(790-795.

[41] United Nations (2018): World Urbanization Prospects, the 2017 Revision. - Population Division D O E A S A, United Nations, New York.

[42] Van Remortel, R. D., Hamilton, M. E., Hickey, R. J. (2001): Estimating the LS factor for RUSLE through iterative slope length processing of digital elevation data within Arclnfo grid. - Cartography 30(1): 27-35.

[43] Verburg, P. H., Soepboer, W., Veldkamp, A., Limpiada, R., Espaldon, V., Mastura, S. S. (2002): Modeling the spatial dynamics of regional land use: the CLUE-S model. Environmental Management 30(3): 391-405.

[44] White, M. D., Greer, K. A. (2006): The effects of watershed urbanization on the stream hydrology and riparian vegetation of Los Peñasquitos Creek, California. - Landscape and Urban Planning 74(2): 125-138.

[45] Wolman, M. G. (1967): A cycle of sedimentation and erosion in urban river channels. Geografiska Annaler Series A Physical Geography 49(2): 385-395.

[46] Yang, D., Kanae, S., Oki, T., Koike, T., Musiake, K. (2003): Global potential soil erosion with reference to land use and climate changes. - Hydrological Processes 17(14): 29132928.

[47] Zhang, L., Nan, Z., Yu, W., Zhao, Y., Xu, Y. (2018): Comparison of baseline period choices for separating climate and land use/land cover change impacts on watershed hydrology using distributed hydrological models. - Science of the Total Environment 622-623: 1016-1028. 